\title{
Soil Water Retention and Soil Compaction Assessment in a Regional-Scale Strategy to Improve Climate Change Adaptation of Agriculture in Navarre, Spain
}

\author{
Rodrigo Antón ${ }^{1}$, Alberto Ruiz-Sagaseta ${ }^{1}$, Luis Orcaray ${ }^{2}$, Francisco Javier Arricibita ${ }^{1}$, Alberto Enrique ${ }^{1}$, \\ Isabel de Soto ${ }^{1}$ (D) and Iñgo Virto ${ }^{1, *(\mathbb{D})}$ \\ 1 Departamento Ciencias, IS-FOOD, Universidad Pública de Navarra, 31006 Pamplona, Spain; \\ rodrigo.anton@unavarra.es (R.A.); alberto.ruiz@unavarra.es (A.R.-S.); arricibita@unavarra.es (F.J.A.); \\ alberto.enrique@unavarra.es (A.E.); isabelsonsoles.desoto@unavarra.es (I.d.S.) \\ 2 Área de Innovación, Sección de Sistemas Sostenibles, Instituto Navarro de Tecnologías e Infraestructuras \\ Agroalimentarias, 31610 Villava, Spain; lorcaray@intiasa.es \\ * Correspondence: inigo.virto@unavarra.es; Tel.: +34-948-169-166
}

\section{check for} updates

Citation: Antón, R.; Ruiz-Sagaseta, A.; Orcaray, L.; Arricibita, F.J.; Enrique, A.; Soto, I.d.; Virto, I. Soil Water Retention and Soil Compaction Assessment in a Regional-Scale Strategy to Improve Climate Change Adaptation of Agriculture in Navarre, Spain. Agronomy 2021, 11, 607. https://doi.org/10.3390/ agronomy 11030607

Academic Editor: Tim Weaver

Received: 17 February 2021

Accepted: 19 March 2021

Published: 23 March 2021

Publisher's Note: MDPI stays neutral with regard to jurisdictional claims in published maps and institutional affiliations.

Copyright: (c) 2021 by the authors. Licensee MDPI, Basel, Switzerland. This article is an open access article distributed under the terms and conditions of the Creative Commons Attribution (CC BY) license (https:// creativecommons.org/licenses/by/ $4.0 /)$.

\begin{abstract}
The aim of this study was to evaluate the effectiveness of the different agricultural management adaptive strategies considered in the framework of a regional climate change adaptation roadmap in Navarre (Spain), from the point of view of soil physical indicators associated to soil compaction and water retention. These indicators were chosen as representative of the potential of these strategies to improve the soil physical condition. That for, the effectiveness of conservation agriculture (CA), crop rotations (ROT), additions of organic matter (ExO), irrigation (IRR) and innovative grassland management (GSS) was assessed by monitoring soil bulk density (BD) and soil available water holding capacity (AWHC) in a network of 159 agricultural fields across homogeneous agro-climatic zones in the region. A sampling protocol designed to compare groups of plots with or without adaptive practices, and with equal soil characteristics within each zone, allowed to determine the effect size of each strategy (measured as response ratios, $R R$, calculated as the relative value of BD and AWHC in fields with adaptive management vs. without). Both parameters responded to soil and crop management, although the observed effect was highly variable. Only the ExO strategy showed an overall positive effect on BD. ROT, IRR and GSS displayed no effect and, in the case of CA, the effect was negative. In terms of AWHC, although the results within the zones were heterogeneous, the overall effect associated to the strategies ROT, ExO, IRR and GSS was neutral, and only CA resulted in an overall negative effect. The observed variability in terms of the effectiveness of the five strategies tested in this region highlights the need to understand the complexity of interrelationships between management and dynamic soil properties at the regional scale.
\end{abstract}

Keywords: CC adaptation; soil compaction; bulk density; water retention; available soil water holding capacity; regional approach; response ratio

\section{Introduction}

Changes in long-term temperature and precipitation patterns associated to climate change can have a major impact on agriculture at global scale, which may determine both the distribution of cropping systems in arable areas and the variation in production over the years $[1,2]$.

Soil may play a key role for assessing and controlling this vulnerability, since changes in soil properties may have profound impacts, both in time and space, on the ability of land to support crops and agricultural management [3]. Soil represents also a dynamic and regulatory system that generates a multitude of functions, which in turn support the provision of ecosystem services by soil and agriculture [4-6]. These functions can also be negatively impacted by climate change [7]. 
In this sense, the main climate drivers to be considered when assessing the vulnerability of agrosystems are those related to temperatures and precipitation patterns, including gradual changes or extreme events, along with others such as rising levels of carbon dioxide and nitrogen in the atmosphere [8,9]. The effect of these drivers on the soil chemical, physical and biological degradation may be varied [8,9]. For instance, functions related to biomass production, nutrient supply and cycling, protection against pests and pathogens, biodiversity conservation, water infiltration and availability, as well as the formation of a stable physical structure in the soil and erosion prevention, could be strongly affected by increased duration and intensity of droughts or higher temperatures [10-12].

At the same time, changes in soil cover and management associated to the intensification of agricultural production, and the increasing demand for natural resources, increase anthropogenic pressure affecting soil properties and leading to soil degradation processes [13]. Understanding alterations in soil properties over time of cultivation, such as the increase in the soil bulk density (BD), the disruption of soil aggregates, or alterations in pores distribution that may affect soil water dynamics [14,15], have been the object of attention for years by researchers, policymakers and farmers focusing on developing soil degradation control strategies $[16,17]$. These strategies should consider not only their potential impact on soil conservation, but also the need for maintaining agricultural yields and, if possible, mitigating the effects of climate change on land degradation [18]. Moving towards adaptive soil management strategies that can adjust to the current or projected conditions of climate drivers by improving the soils resilience, may thus allow to moderate or avoid these negative impacts, by promoting soil restoration [19]. The limitations of these strategies are site-specific and determined through the interaction of biochemical and physical factors as well as the social and institutional framework considered $[1,20,21]$. In Europe, an evidence of the current interest in this matter are the European Commission proposal of alignment of the Common Agricultural Policy (CAP)with the European Union's environmental, climate, and biodiversity protection commitments set in the European Green Deal [22-24] or the recent European Commission evaluation support study on the impact of CAP on sustainable soil management [25].

An adequate assessment of the response of agricultural soils to such strategies requires the use of indicators, which should be as sensitive as possible to changes in soil functions, and to possible alterations in management and/or climate [26,27]. A number of indicators linked to soil functions have been designed, which are related to soil physical, chemical and biological properties that can be monitored in the context of sustainable land management, soil degradation and climate change adaptation $[8,28,29]$. The most frequently used ones, because of their relevance in soil functioning and climate change mitigation, are those related to soil organic C (SOC) storage and cycling. Many studies have highlighted the potential and limitation of different strategies in improving SOC in agricultural soils $[18,30,31]$.

However, although recent global initiatives to promote SOC storage in agricultural soils highlight that the interest of this increase lays also on its potential to improve soil condition and the functioning of agrosystems, as benefits associated with SOC gains [32,33], soil physical indicators, which can add useful information on the effectiveness of management strategies to changes in rainfall patterns or water balances, are less often addressed. These indicators can be of great interest in regional contexts. Those related to soil water retention and soil compaction are the most frequently used [34]. Soil water retention is sensitive to management strategies, which implies that these strategies may induce a positive or negative response to changes in climate, especially to variable and high intensity rainfall or drought events. In the same sense, soil compaction, as expressed by BD [35], represents an adequate indicator of soil associated with multiple soil functions such as aeration, root development and infiltration [8].

Together with the lower attention paid to these indicators. The effects of most of the adaptive soil management strategies in terms of the restoration of the soils physical condition are not always well known or straightforward. For instance, although manure 
application generally improves soil water retention and BD [36,37], Blanco-Canqui et al. [35] suggest that changes in these soil properties may be small or not be measurable in the short term under field conditions ( $<5$ year). The effect of tillage reduction or suppression has been linked to greater soil water retention in different agro-climatic conditions $[38,39]$. Their consequences in BD ant total porosity are less clear, with most studies reporting increased BD without tillage [40], but a trend of this effect to decrease with increasing experimental duration [41] and the variety of crops considered [42].

The effects of crop rotation on the soil physical properties show also inconsistent results. Factors such as the crops included in the rotation, intensification and soil management system seem to be determinant in this sense [43,44]. A similar dependency on local conditions has been observed for the link between controlled grazing and other conservation management strategies for grassland soils, and the soil physical condition [45]. This implies that the assessment of these soil management strategies aiming to improve soil water conservation and the soil physical status requires careful knowledge of the soil factors affecting them [46,47]. The effect of other adaptive strategies not directly related to soil management, such as the adoption of irrigation, seems more related too to the local soil and crops management techniques than to the use of irrigation by itself [48].

In this context, the main objective of this work was to carry out a quantitative assessment of the effectiveness of a number of agricultural practices in achieving an improvement in the soil water retention, assessed as its available water holding capacity (AWHC) and in $\mathrm{BD}$, at the scale of the region of Navarre, in Northern Spain. These strategies were those already being implemented by some farmers in the region, with a potential to reduce the vulnerability of agricultural land to the projected regional climate change by improving the soil resilience to a gradual increase of temperature, heat waves, changes in rainfall patterns and an increase in the number and frequency of extreme precipitation events [49]. The work was conducted within the framework of the European Strategy for Adaptation to Climate Change [50], the regional climate change roadmap in the region of Navarre (Spain) [49] and a regional-scale project (LIFE Nadapta) launched in 2017 in the region, with the goal of advancing towards a comprehensive design of climate change adaptation policies. In this sense, the study aimed to set a regional monitoring network of sites, in line with the challenging need for up-scaling studies on soil quality [51,52].

For this purpose, a first objective was to define the actual baseline of these soil physical indicators under conventional management conditions in the territory, by monitoring a representative number of agricultural fields in different agroclimatic areas. Then, we aimed to study the effect of the most relevant agricultural practices promoted in the regional roadmap for climate change adaptation on $\mathrm{AWHC}$ and $\mathrm{BD}$, in a selection of representative agricultural fields across the region.

\section{Materials and Methods}

\subsection{Study Area}

The Autonomous Community of Navarre $\left(10,391 \mathrm{~km}^{2}\right)$ is located in the North of Spain (Figure 1). The region is characterized by high climatic variability, with a rainfall gradient ranging from $>2500 \mathrm{~mm}$ in the $\mathrm{N}$ to $<350 \mathrm{~mm}$ in the SE [53], as the most significant natural division in the territory. Mean annual temperatures vary between $14.5^{\circ} \mathrm{C}$ (in Buñuel, $41^{\circ} 58^{\prime} 47^{\prime \prime} \mathrm{N} ; 1^{\circ} 26^{\prime} 38^{\prime \prime} \mathrm{W}$ ) and $9.3^{\circ} \mathrm{C}$ (in Irabia, $42^{\circ} 59^{\prime} 07^{\prime \prime} \mathrm{N} ; 1^{\circ} 09^{\prime} 28^{\prime \prime} \mathrm{W}$ ), with a more or less marked seasonal oscillation depending on altitude, proximity to the sea, and latitude [54]. At present, 39\% of the total area is used as agricultural land (90.7\% cropland and $9.3 \%$ grassland). 


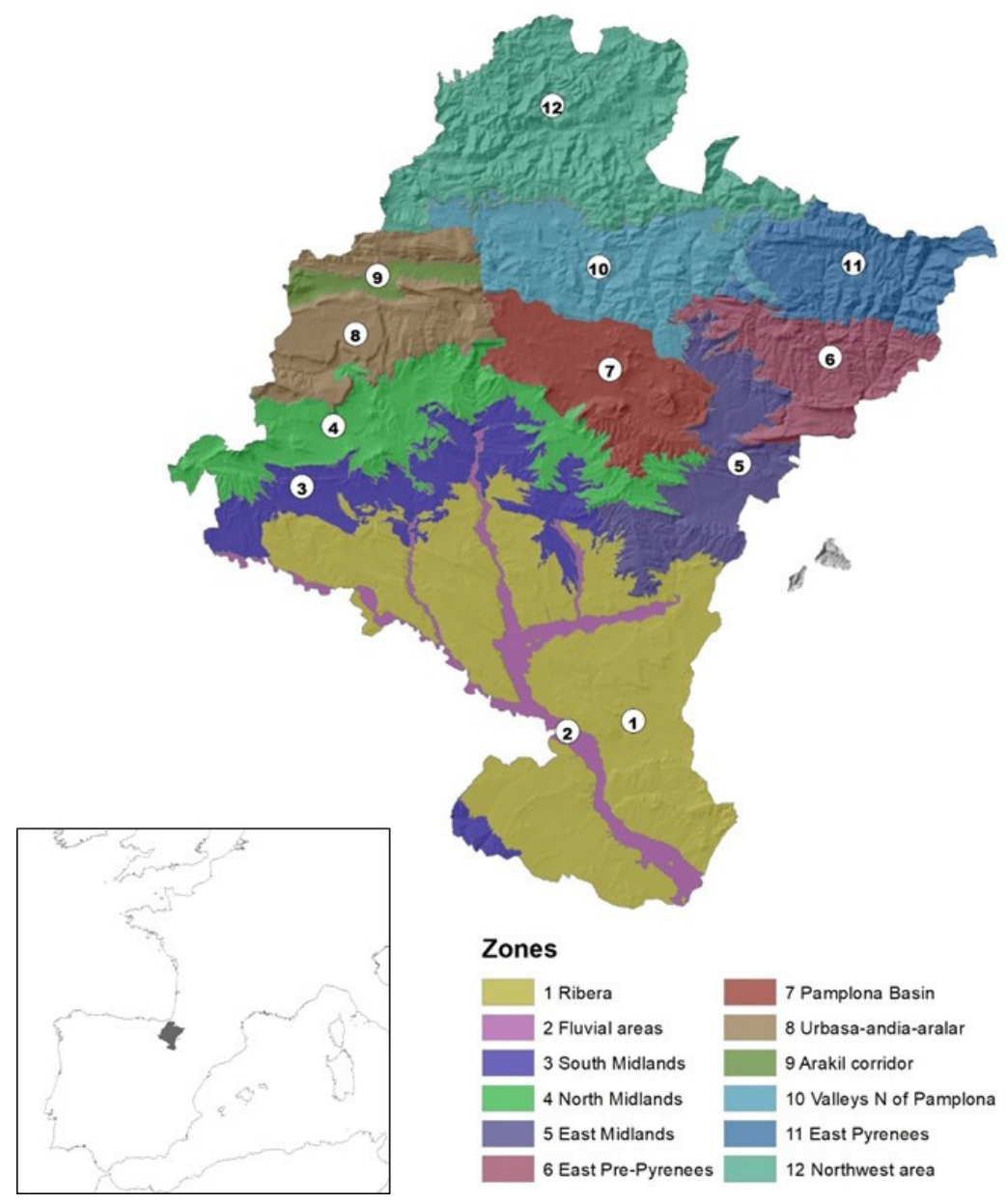

Figure 1. Location of the region of Navarre (bottom left) and homogeneous zones defined for this study.

\subsection{Selection of Soil Management Strategies}

The agricultural managements considered in this study were those selected as adaptive in the regional action plans for climate change adaptation [49], and most commonly found in the region. They were conservation agriculture (CA), management of exogenous sources of organic $\mathrm{C}(\mathrm{ExO})$, and rotations (ROT), as cropping strategies in extensive crops. Other managements of regional interest, i.e., the implementation of irrigation (IRR), and optimized grasslands management (GSS), were also included. CA included no-till in extensive crops and permanent grass cover in permanent woody crops. ExO included the regular addition of different sources of organic matter at agronomic doses (i.e., with the purpose of fertilization), ROT included different crops in the regular sequence of cultivation. IRR was tested in plots with irrigation, and GSS included mostly controlled grazing strategies, and in some cases, in combination with lay or lay/crops rotations. Some of these practices are among those recently identified as those for which a better understanding of the processes and changes in the soil associated with SOC gains or losses is needed [18].

\subsection{Homogeneous Areas and Network of Agricultural Plots}

In the framework of the project LIFE Nadapta, twelve homogeneous zones were defined by combining biogeographical and vegetation series information (Figure 1) so that each zone had homogeneous conditions for plant growth [55,56].

Within those zones representing the highest proportion of agricultural land in the region (zones 1, 3, 4, 5, 7, 10 and 11), the most common land uses were identified and a 
network of agricultural plots were identified in order to evaluate the different strategies considered. Plots included in this network were organized in groups on the main soil types in each of the seven zones. Within each of these groups, reference plots (where one of the adaptive managements had been applied for at least five years consecutively) were identified, with the assistance of famers, farmers' unions and extension agents. At the same time, contiguous or nearly plots with the same crop or type of crop, and under conventional management were also identified and included in the group. Each group of plots included therefore the reference fields and several plots under conventional management. The definition of conventional management was done according to the most extended managements in the region, for each of the systems evaluated. That implied mineral fertilization in the case of ExO, non-irrigated plots in the case of IRR, annual monoculture for the ROT strategy, and regular mowing and/or no rotation in the case of GSS. In the case of CA, conventional management implied inversion tillage in nonpermanent crops, and frequent tillage to keep the soil free of vegetation between and under the rows of woody crops where permanent grass cover was considered as CA.

Considering the diversity of agricultural land uses existing in the region, the information related to plots within each group was classified firstly by principal soil groups and, secondly, by management, irrigation regime and crop intensity, when necessary. In this sense, in plots under CA and ROT strategies, the irrigation regime of the groups considered was specified. For the plots within the ExO strategy, both the origin of the organic source applied and the irrigation regime were defined, and, in the case of IRR, the cropping intensity was divided into annual crops (usually corn) and intensive-irrigation (with more than one crop per year). The irrigation system in all the irrigated plots was sprinkler irrigation. In this sense, rainfed regimes normally corresponded to extensive cereal crops.

The number of groups of plots per zone was determined considering the extension of agricultural land, and the diversity of strategies adopted, in each zone. The selection of plots within each group was done keeping the highest possible physical proximity between them in order to guarantee soil homogeneity within each group (see sampling strategy below). Climate and soils characteristics, including average SOC stocks measured in the conventionally-managed plots at $0-20 \mathrm{~cm}$, as well as management strategies within each zone and the number of groups and plots, are compiled in Table 1.

Table 1. Climate [57], average SOC stock in conventionally-managed plots at $0-20 \mathrm{~cm}$ (Mean \pm standard deviation), management strategies, number of groups and plots, and soil groups [58]. Managements are conservation agriculture (CA), addition of exogenous sources of organic $\mathrm{C}(\mathrm{ExO})$, rotations (ROT), irrigation (IRR), and controlled grazing and/or rotation in grasslands (GSS).

\begin{tabular}{|c|c|c|c|c|c|c|}
\hline \multirow[b]{2}{*}{ Zone } & \multirow{2}{*}{$\begin{array}{l}\text { Climate } \\
\text { Papadakis [57] }\end{array}$} & \multirow{2}{*}{$\begin{array}{l}\text { SOC Stock } \\
0-20 \mathrm{~cm}\left(\mathrm{Mg} \mathrm{ha}^{-1}\right)\end{array}$} & \multicolumn{3}{|c|}{ Management Strategies and Plots } & \multirow[b]{2}{*}{ Soil groups [58] } \\
\hline & & & Strategies & Groups & Plots & \\
\hline 1. Ribera & $\begin{array}{l}\text { Mild Steppe (AvM-Ost) and Dry } \\
\text { Temperate Mediterranean } \\
(\text { AvMMe) }\end{array}$ & $38.2 \pm 9.7$ & $\begin{array}{l}\text { CA } \\
\text { ExO } \\
\text { ROT } \\
\text { IRR } \\
\text { GSS }\end{array}$ & $\begin{array}{l}5 \\
8 \\
3 \\
4 \\
2\end{array}$ & $\begin{array}{l}12 \\
26 \\
13 \\
16 \\
6\end{array}$ & $\begin{array}{l}\text { Fluventic Inceptisols and Entisols, } \\
\text { Orthents, Xerepts, Xerolls, Ustolls, } \\
\text { Calcids, Gypsids }\end{array}$ \\
\hline 3. South Midlands & $\begin{array}{l}\text { Dry Temperate } \\
\text { Mediterranean (AvMMe) }\end{array}$ & $34.7 \pm 7.4$ & $\begin{array}{l}\text { CA } \\
\text { ExO } \\
\text { ROT }\end{array}$ & $\begin{array}{l}3 \\
4 \\
4\end{array}$ & $\begin{array}{l}9 \\
13 \\
12\end{array}$ & $\begin{array}{l}\text { Fluventic inceptisols and entisols, } \\
\text { Other Xerepts, Xerepts with depth } \\
\text { limitations, Ustolls }\end{array}$ \\
\hline 4. North Midlands & $\begin{array}{l}\text { Moist Temperate } \\
\text { Mediterranean (AvMMe) }\end{array}$ & $49.0 \pm 20.1$ & $\begin{array}{l}\text { ExO } \\
\text { IRR }\end{array}$ & $\begin{array}{l}1 \\
2\end{array}$ & $\begin{array}{l}4 \\
4 \\
\end{array}$ & $\begin{array}{l}\text { Xerepts with depth limitations, } \\
\text { Other Xerepts }\end{array}$ \\
\hline 5. East Midlands & $\begin{array}{l}\text { Moist Temperate } \\
\text { Mediterranean (AvMMe) }\end{array}$ & $38.2 \pm 7.8$ & $\begin{array}{l}\text { ExO } \\
\text { GSS }\end{array}$ & $\begin{array}{l}1 \\
1\end{array}$ & $\begin{array}{l}4 \\
5\end{array}$ & $\begin{array}{l}\text { Orthents, Xerepts with depth } \\
\text { limitations }\end{array}$ \\
\hline 7. Pamplona Basin & $\begin{array}{l}\text { Moist Temperate } \\
\text { Mediterranean (AvMMe) }\end{array}$ & $38.9 \pm 6.0$ & $\begin{array}{l}\text { CA } \\
\text { ExO } \\
\text { ROT }\end{array}$ & $\begin{array}{l}2 \\
2 \\
2\end{array}$ & $\begin{array}{l}6 \\
7 \\
6\end{array}$ & $\begin{array}{l}\text { Xerepts, Orthents, Fluventic } \\
\text { inceptisols and entisols }\end{array}$ \\
\hline $\begin{array}{l}\text { 10. Valleys } \mathrm{N} \\
\text { of Pamplona }\end{array}$ & $\begin{array}{l}\text { Cool Maritime Mediterranean } \\
\text { (AvTrME) }\end{array}$ & $92.4 \pm 9.8$ & GSS & 3 & 8 & Orthents, Udepts \\
\hline 11. East Pyrenees & Cool Maritime (AvTrHU) & $55.0 \pm 2.1$ & GSS & 1 & 5 & Orthent, Fluventic Udepts \\
\hline 12. Northwest area & $\begin{array}{l}\text { Cool Maritime (AvTrHU) and } \\
\text { Warm Maritime (AvMHU-Hu) }\end{array}$ & $142 \pm 17.1$ & GSS & 1 & 3 & Alfisols, Ultisols \\
\hline
\end{tabular}




\subsection{Soil Sampling Design and Analysis}

A sampling strategy was developed to ensure that, within each group, areas with homogeneous soil characteristics and differing only in management were compared. That for, in each plot of the group, a sampling area was determined so that sampled areas in each group of plots corresponded to the same soil unit for all plots within the group, following the methodology described in Antón et al. [48]. Attention was paid to generate zones that were as homogeneous as possible, considering in addition to the soil type criterion, others such as slope or orientation $[59,60]$. That for, the delimitation of these homogeneous areas within each group of plots was carried out on the basis of the highest available detail (soil series or phase). The regional soil map at 1:25,000 [61] was used in the areas where it was available. In this map, soil units are delimited, among other parameters, by slope and position in the landscape. Where this was not the case, the delimitation was made from soil information available at 1:50,000, geological information and photo-interpretation. In all cases, the process was completed with a field visit to verify the final result, and with extra soil profiles description when necessary.

Then, for the sampling area of each plot within each group, a sampling design was adapted following the one described by Stolbovoy et al. [62] for comparing SOC stocks changes in croplands. In this protocol, a randomized grid template is adapted to the size of the sampling area and used to define at least three representative sampling squares per sampling zone (i.e., areas with the same type of soil in each plot of the group). This sampling design allowed for selecting the sampling areas considering also the particular conditions of slope and orientation in the sampling area, and therefore granted random and representative topsoil sampling. As such, it was considered valid to ensure that comparison units were as homogeneous as possible in relation to the invariant soil properties and could reflect the variability of the indicators sensitive to management, as recommended by [52].

All the processing of cartographic information was performed with ArcGIS 10.6 (Environmental Systems Research Institute, Inc., Redlands, CA, USA 2018).

Sampling was conducted at the end of the growing season of each crop, or as far as possible from the last soil alteration with management in permanent crops to avoid possible seasonal variations in $\mathrm{BD}[63,64]$. Within each of the square sampling areas, 25 subsamples evenly distributed were carefully collected with a shovel at $0-30 \mathrm{~cm}$, to compile a composite sample. One $100 \mathrm{~cm}^{3}$ undisturbed soil core was taken at the center of the 0-30-cm depth interval. Disturbed samples were gently mixed and broken apart in large clods, and air-dried. Part of each sample was then sieved at $2 \mathrm{~mm}$. The stone content was determined while sieving.

Intact large clods and sieved samples $0-30 \mathrm{~cm}$ ) were used to measure soil water retention (SWR) at -33 and $-1500 \mathrm{kPa}$, respectively, considered as the soil moisture content at field capacity and wilting point [65]. SWR was determined for each sample in 5 and 15 bar pressure plate extractors (Soil Moisture Equipment Corp., Santa Barbara, CA), as described by Dirksen [66]. Volumetric values for the SWR were calculated from the gravimetric measures using BD, determined from the oven-dry $\left(105^{\circ} \mathrm{C}\right)$ mass of the undisturbed $100-\mathrm{cm}^{3}$ cores. Soil AWHC was calculated from the difference in soil moisture content at field capacity $(-33 \mathrm{kPa})$ and wilting point $(-1500 \mathrm{kPa}), \mathrm{BD}$ data and depth. Stoniness was used for correction when needed.

\subsection{Bulk Density and Soil Water Retention Assessment and Statistics}

Data on BD and volumetric soil AWHC were first used to make a comparison at the regional level between the different zones identified, and at a local level in each zone, between different soil typologies. This first approximation was made in plots under conventional management, aiming to capture the reference level or baseline of the region's agricultural soils, considering that physical and hydraulic degradation processes in these soils had reach a relatively steady state after decades of cultivation [67]. Data are provided as means \pm standard deviation and the homogeneity of variances was verified by the Levene test. A univariate analysis of variance (ANOVA) was used to assess differences 
between groups, and post hoc analysis was performed by the Duncan's test. Significant results were based on a probability level of $p<0.05$.

The second approximation involved the study of the effect of each strategy considered on BD and volumetric soil AWHC. This effect was measured for each group of plots according to the natural logarithm of the response ratio (LRR):

$$
\mathrm{LRR}=\ln \left(\frac{\bar{X}_{R}}{\bar{X}_{C}}\right)
$$

where $\bar{X}_{R}$ and $\bar{X}_{C}$ are the mean values in the reference plot or plots with adaptive management, and those under conventional management within each group, respectively. This represents a practical way to quantify and summarize the magnitude and direction of the results, allowing to linearize and normalize the sampling distribution [68]. The variance of the LRR for each group was calculated following these authors as:

$$
\operatorname{var}(\mathrm{LRR})=\frac{\left(\mathrm{SD}_{\mathrm{R}}\right)^{2}}{\mathrm{n}_{\mathrm{R}} \overline{\mathrm{X}}_{\mathrm{R}}^{2}}+\frac{\left(\mathrm{SD}_{\mathrm{C}}\right)^{2}}{\mathrm{n}_{\mathrm{C}} \overline{\mathrm{X}}_{\mathrm{C}}^{2}}
$$

where SD and $\mathrm{n}$ indicate the standard deviations and the sample size of the reference and conventional plots within each group of plots, respectively.

Following the approach commonly applied in meta-analyses comparing results on the same parameters from different study areas, the overall effects of each strategy in the zones with more than one group of plots, and at the regional scale, were analyzed with an unweighted fixed effects (FE) model. This model assumes that all groups share a common value of LRR [68], considering that the only source of variability in the analysis is that associated to the sampling process within each group, calculated according to Equation (2). The unweighted analysis assigns the same weight to each group, avoiding the underestimation of the LRR due to differences in sample sizes.

The LRRs for different strategies at group, zone and regional levels were represented in forest graphs, transformed into RR for simplification. The effect was considered significant when the $95 \%$ confidence interval (CI) of the RR did not overlap one $(\alpha=0.05)$. All statistical analyses were carried out with R (R Core Team; 2019). Calculations and model performance for RR analysis were carried out using the metafor package [69].

In order to complete the discussion, data on SOC from a previous analysis were taken into account, both in terms of SOC stocks at reference plots (Table 1) and in terms of the overall regional effect of each strategy on this parameter (Table 2).

Table 2. Overall regional RR effect and 95\% confidence interval on SOC for each strategy. Managements are conservation agriculture (CA), addition of exogenous sources of organic $C(E x O)$, rotations (ROT), irrigation (IRR), and controlled grazing and/or rotation in grasslands (GSS).

\begin{tabular}{lll}
\hline Strategy & SOC Overall RR Effect $(\%)$ & $\mathbf{9 5} \%$ Confidence Interval \\
\hline ROT & 0.9 & $0.84-0.96$ \\
GSS & 1.27 & $1.13-1.42$ \\
IRR & 1.25 & $1.17-1.34$ \\
ExO & 1.31 & $1.25-1.37$ \\
CA & 1.24 & $1.16-1.31$ \\
\hline
\end{tabular}

\section{Results}

\subsection{Baseline by Agricultural Zones and Soil Type: Bulk Density}

Figure 2 shows the results of BD $(0-30 \mathrm{~cm})$ corresponding to the plots under conventional management in each of the areas evaluated. These results showed a very large variability, with values ranging from below $0.9 \mathrm{~g} \mathrm{~cm}^{-3}$ at some points in zone 10, to values close to $1.9 \mathrm{~g} \mathrm{~cm}^{-3}$ in zone 4 , for the depth studied. 


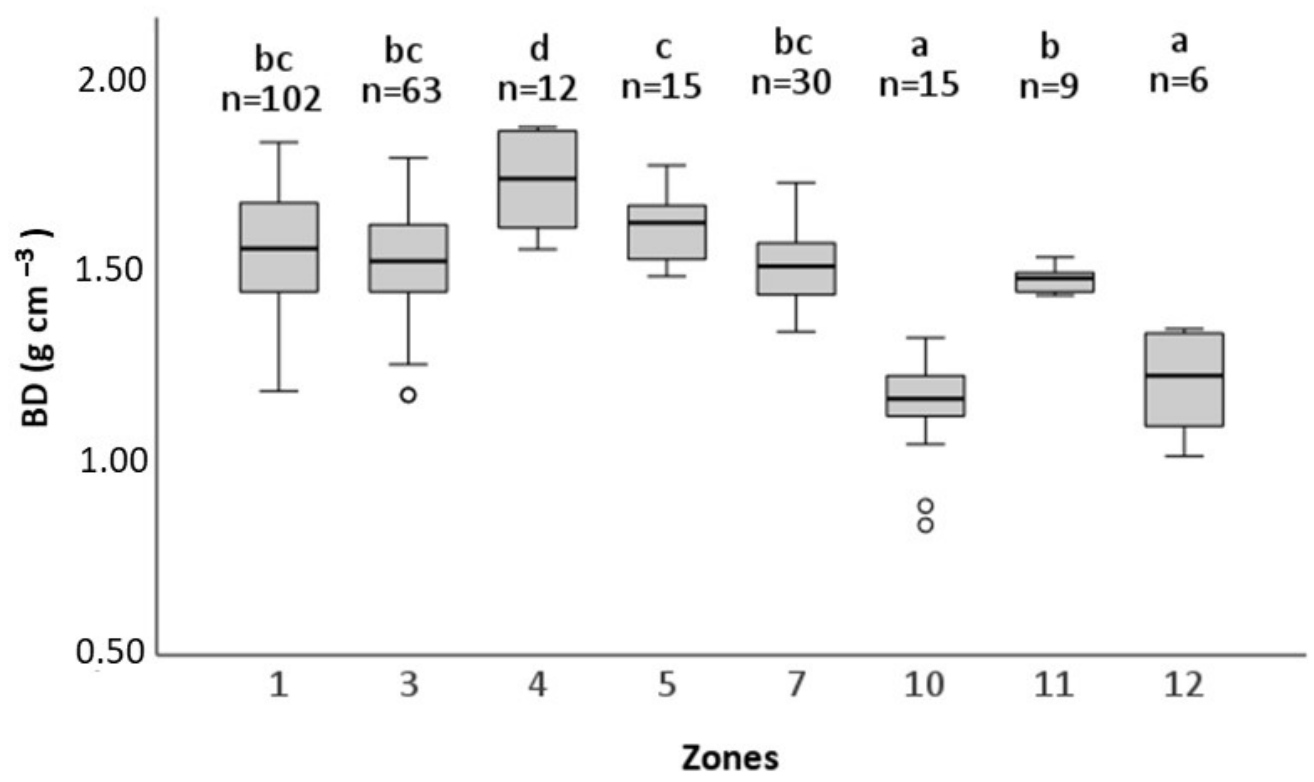

Figure 2. Bulk density (BD) in conventionally managed topsoils $(0-30 \mathrm{~cm})$ in each of the zones selected for this study. Center lines show the medians, box limits indicate the 25th and 75th percentiles, whiskers extend 1.5 times the interquartile range from the 25th and 75th percentiles, outliers are represented by dots. Values marked with different letters are significantly different $(p<0.05)$ according to ANOVA. Values showing the same letter belong to the same homogeneous group according to Duncan's test. Open circles are outliers.

Zones 10 and 12, with $1.15 \pm 0.14 \mathrm{~g} \mathrm{~cm}^{-3}$ and $1.21 \pm 0.13 \mathrm{~g} \mathrm{~cm}^{-3}$ respectively, had lower average $\mathrm{BD}$ values than the rest. Zone 4 displayed values significantly above the others, with an average BD of $1.74 \pm 0.14 \mathrm{~g} \mathrm{~cm}^{-3}$. The rest of zones were grouped with an average value of $1.54 \pm 0.11 \mathrm{~g} \mathrm{~cm}^{-3}$, with zones 5 and 11 outstanding above and below, with BD values of $1.62 \pm 0.10 \mathrm{~g} \mathrm{~cm}^{-3}$ and $1.48 \pm 0.04 \mathrm{~g} \mathrm{~cm}^{-3}$, respectively.

Figure 3 shows the BD results corresponding to the top layer $(0-30 \mathrm{~cm})$ in the different soil types within each zone. These results showed differences in zones $1,3,4$ and 7 . In zone 1 , all soils were fairly homogeneous, although the Xerepts BD $\left(C, 1.61 \pm 0.13 \mathrm{~g} \mathrm{~cm}^{-3}\right)$ was significantly higher than the Orthens BD $\left(\mathrm{F}, 1.42 \pm 0.05 \mathrm{~g} \mathrm{~cm}^{-3}\right)$. Soils grouped as Ustolls (B) showed a higher BD value than Xerepts with depth limitations soils (D) in zone 3, with $1.69 \pm 0.00 \mathrm{~g} \mathrm{~cm}^{-3}$ and $1.47 \pm 0.00 \mathrm{~g} \mathrm{~cm}^{-3}$ respectively. The two types of soils included in Zone 4, Xerepts (C) and Xerepts with depth limitations (D) showed significant differences between them with BD values of $1.61 \pm 0.0 \mathrm{~g} \mathrm{~cm}^{-3}$ and $1.87 \pm 0.01 \mathrm{~g} \mathrm{~cm}^{-3}$, respectively. In zone 7, the BD of soils grouped as Orthens (F, $1.65 \pm 0.07 \mathrm{~g} \mathrm{~cm}^{-3}$ ) was significantly higher than that of Xerepts (C), and of those grouped as Fluventic inceptisols and Entisols $(G)$, $1.51 \pm 0.06 \mathrm{~g} \mathrm{~cm}^{-3}$ and $1.48 \pm 0.09 \mathrm{~g} \mathrm{~cm}^{-3}$.

\subsection{Baseline by Agricultural Zones and Soil Type: AWHC}

Regarding the results of volumetric soil AWHC in the first $30 \mathrm{~cm}$, represented in Figure 4, an important variability was observed at regional level. However, the same trend observed in the BD analysis was confirmed, since average soil AWHC in zones 10 and 11, with $61.17 \pm 11.8 \mathrm{~mm}$ and $70.31 \pm 7.99 \mathrm{~mm}$ respectively, was significantly higher than the others. The rest of the zones showed fairly homogeneous values, although zones 3 and 12 showed values significantly higher than zone 4 . 

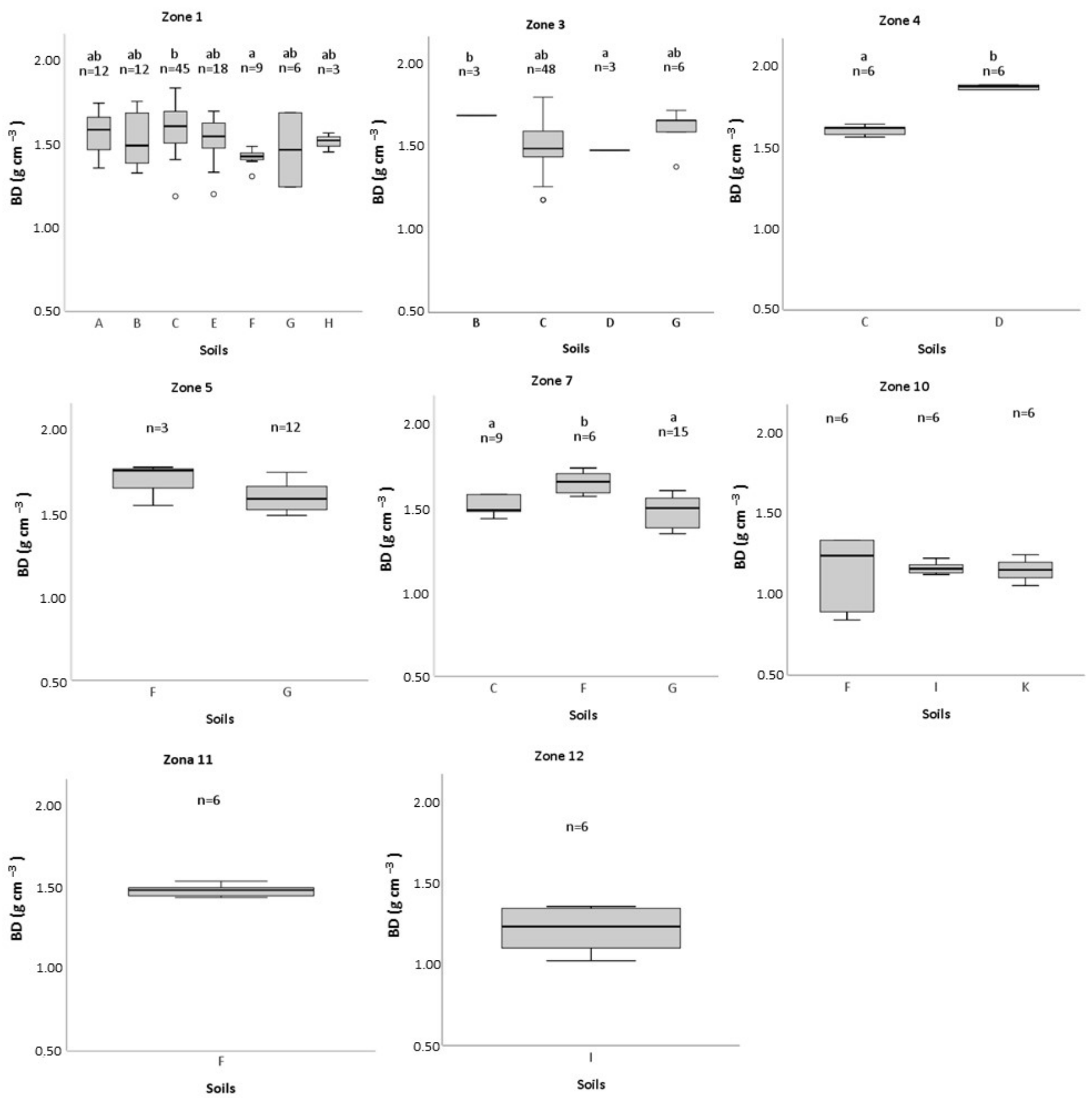

Figure 3. Bulk density (BD) in conventionally managed topsoils $(0-30 \mathrm{~cm})$ for the different types of soils in each zone selected for this study. Center lines show the medians, box limits indicate the 25th and 75th percentiles, whiskers extend 1.5 times the interquartile range from the 25 th and 75 th percentiles, outliers are represented by dots. Values showing the same letter belong to the same homogeneous group according to Duncan's test $(p<0.05)$. A: Xerolls, B: Ustolls, C: Xerepts, D: Xerepts with depth limitations, E: Calcids, F: Orthents, G: Fluventic Inceptisols and Entisols; H: Gypsids; I: Udepts; J: Fluventic Udepts, K: Humults [58]. Open circles are outliers. 


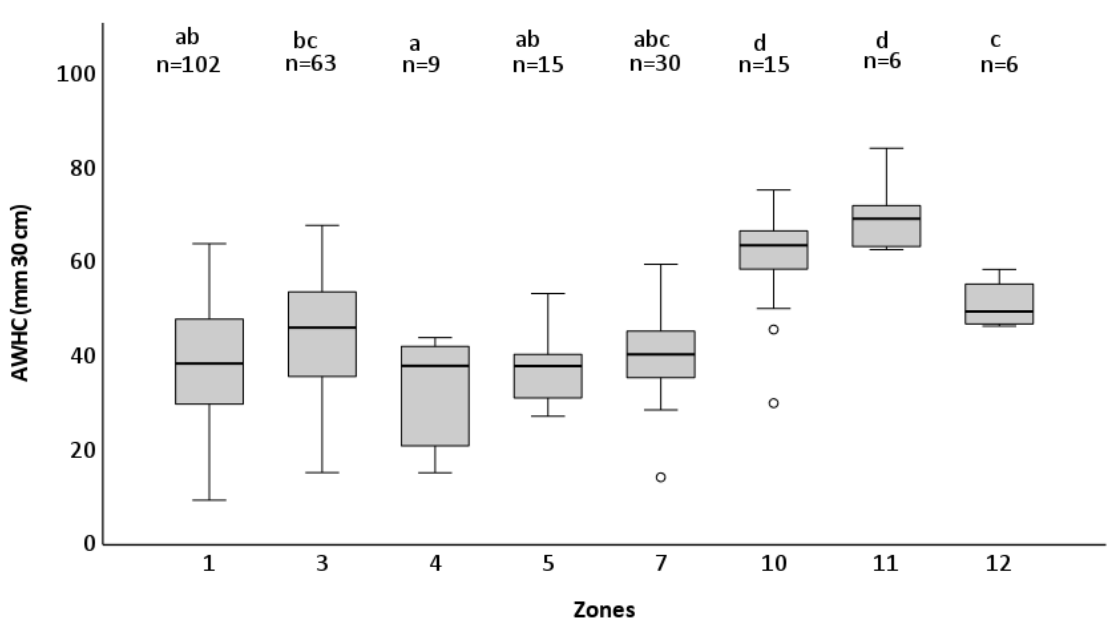

Figure 4. Volumetric soil AWHC $(0-30 \mathrm{~cm})$ in each of the zones selected for this study. Center lines show the medians, box limits indicate the 25 th and 75 th percentiles, whiskers extend 1.5 times the interquartile range from the 25th and 75th percentiles, outliers are represented by dots. Values marked with different letters are significantly different $(p<0.05)$ according to ANOVA. Values showing the same letter belong to the same homogeneous group according to Duncan's test. Open circles are outliers.

Figure 5 shows the results of volumetric soil AWHC of the upper soil layer $(0-30 \mathrm{~cm})$ in the different types of soil within each zone considered. Significative differences between soil types were found in zones 1, 3, 4, 5, 7 and 10. In zone 1, all soils were fairly homogeneous in terms of AWHC, although the groups categorized as Calcid (E, $51.30 \pm 10.01 \mathrm{~mm}$ ), Orthents $(\mathrm{F}, 41.37 \pm 6.43 \mathrm{~mm})$ and Fluventic inceptisols and Entisols $(\mathrm{G}, 47.52 \pm 16.88 \mathrm{~mm})$ appeared significantly higher than Xerolls $(A, 27.95 \pm 11.05 \mathrm{~mm}$ ). In zone 3, the group of Xerepts with depth limitations $(\mathrm{D}, 59.49 \pm 1.38 \mathrm{~mm})$ showed a significantly higher value than soils grouped as Fluventic Inceptisols and Entisols (G, $40.47 \pm 7.97 \mathrm{~mm}$ ). In zone 4, the group of Xerepts (C) showed a significantly higher value than soils categorized as Xerepts with depth limitations (D), with $40.93 \pm 3.36 \mathrm{~mm}$ and $17.37 \pm 3.21 \mathrm{~mm}$ respectively. In zone 5, the Orthents soil group (F, $46.93 \pm 5.95 \mathrm{~mm}$ ) showed a significantly higher AWHC value than soils categorized as Fluventic Inceptisols and Entisols (G, $35.04 \pm 5.30 \mathrm{~mm})$. The three soils included in zone 7 showed significant differences between them. The Orthents soil group (F) showed the highest value $(46.93 \pm 5.95 \mathrm{~mm})$ followed by Xerepts $(C, 40.07 \pm 7.78 \mathrm{~mm})$ and Fluventic inceptisols and entisols group (G), with $31.41 \pm 8.98 \mathrm{~mm}$. Finally, soils categorized as Orthents $(\mathrm{F})$ showed a significantly lower AWHC value $(50.51 \pm 11.39 \mathrm{~mm})$ than the rest of groups within zone 10, with an average AWHC value of $69.79 \pm 1.35 \mathrm{~mm}$.

\subsection{Effect of Management on Bulk Density}

Figures 6-10 show the results of the effect of the five strategies considered on BD, expressed as RR for each group of plots, together with the effect per zone and the overall effect associated to the whole region. It should be noted that, in the case of the BD analysis, the values of the RR above one represent an increase in BD with respect to non-adaptive management [70], so that the positive effect in this case is represented by RR intervals below 1 . 

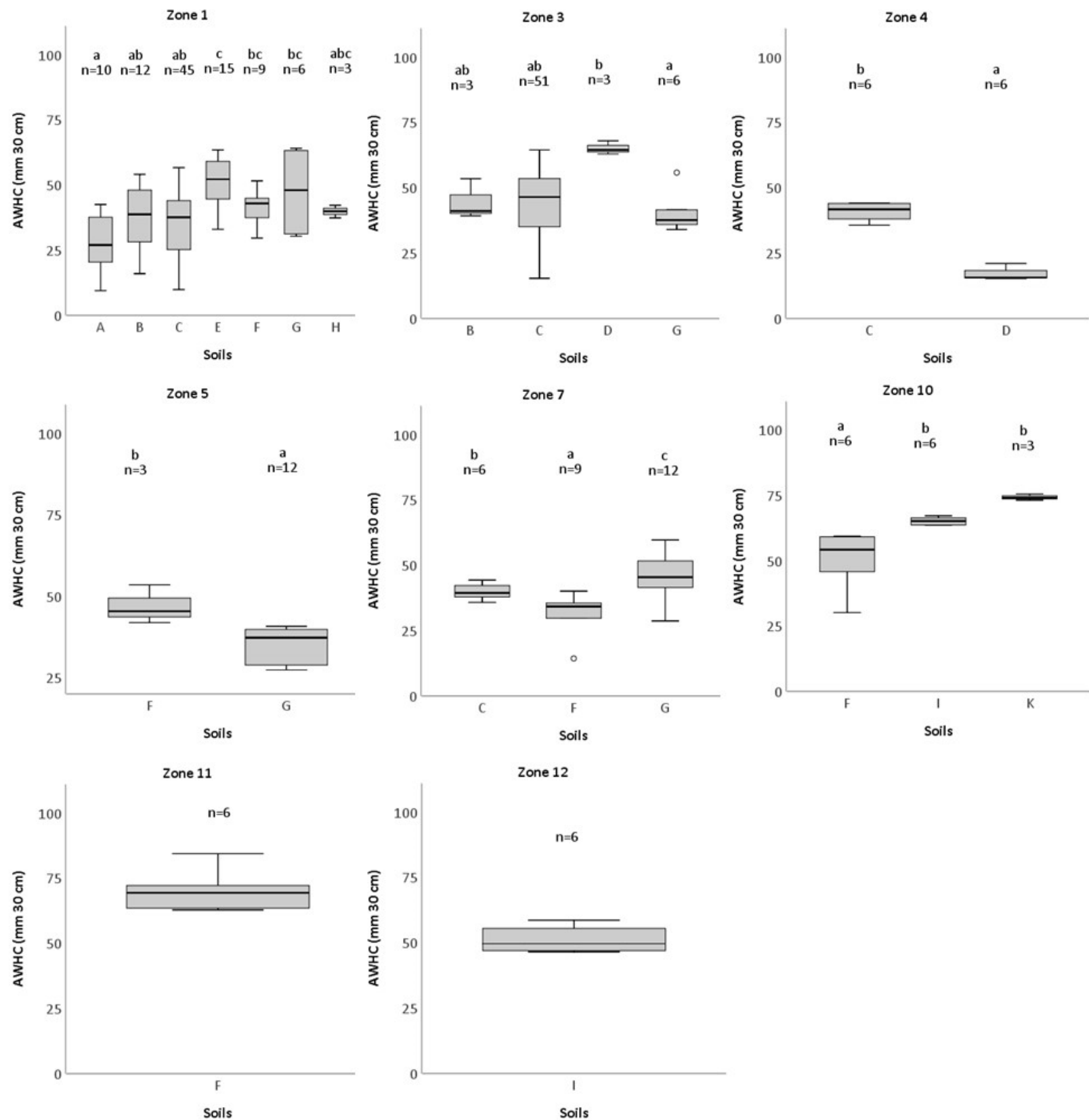

Figure 5. Volumetric soil AWHC in conventionally managed topsoil $(0-30 \mathrm{~cm})$ for the different types of soils in each zone selected for this study. Center lines show the medians, box limits indicate the 25th and 75th percentiles, whiskers extend 1.5 times the interquartile range from the 25 th and 75 th percentiles, outliers are represented by dots. Values showing the same letter belong to the same homogeneous group according to Duncan's test $(p<0.05)$. A: Xerolls, B: Ustolls, C: Xerepts, D: Xerepts with depth limitations, E: Calcids, F: Orthents, G: Fluventic Inceptisols and Entisols; H: Gypsids; I: Udepts, J: Fluventic Udepts, K: Humults [58]. Open circles are outliers. 


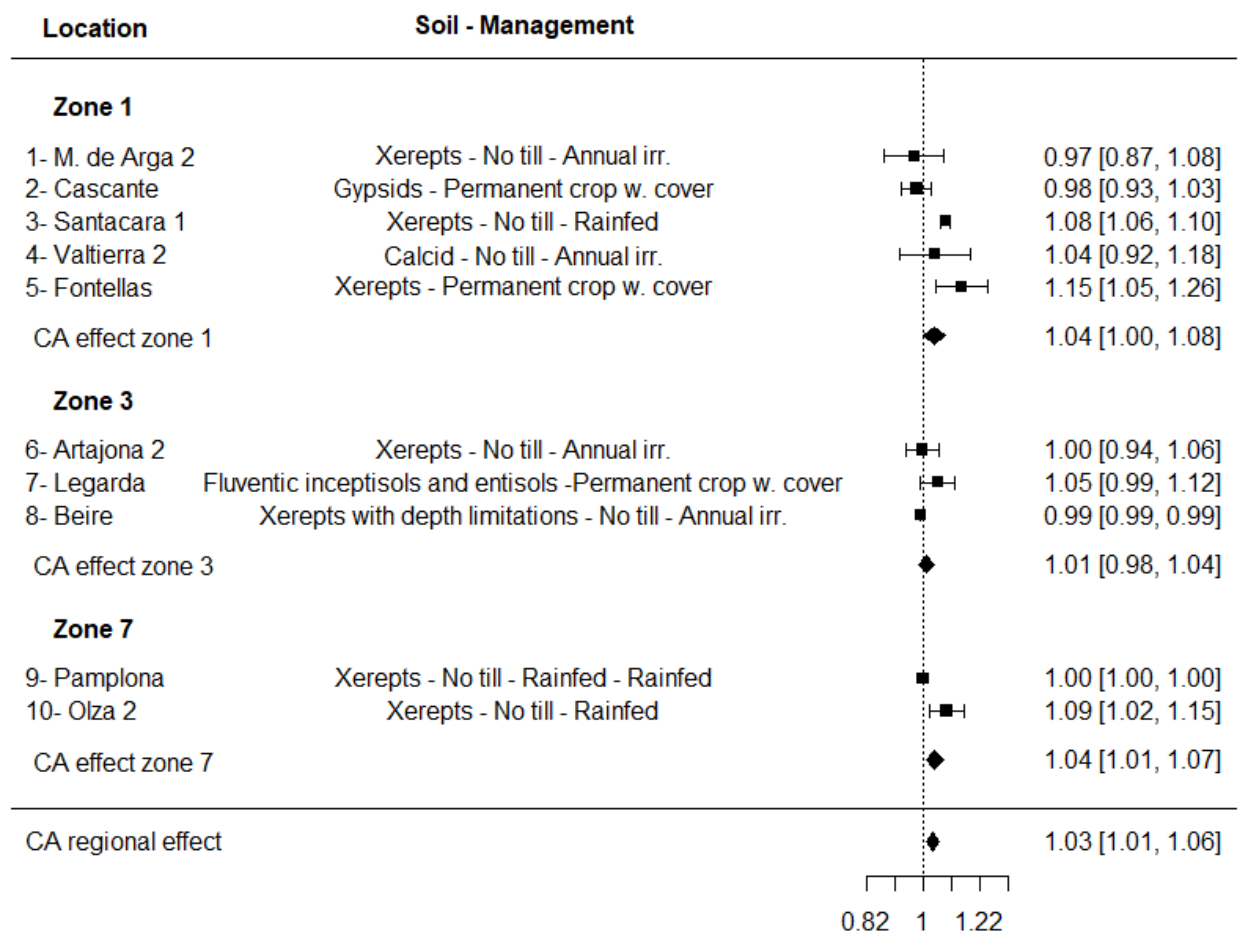

Figure 6. Response ratio $(\mathrm{RR})$ of $\mathrm{BD}(0-30 \mathrm{~cm})$ for the adaptive management strategy of conservation agriculture (CA). Zones correspond to those in Figure 1. The effect was considered significant when the $95 \%$ confidence interval (CI) of the RR did not overlap one $(\alpha=0.05)$. Soil and management column includes information about principal soil group, strategic management considered and irrigation regime in each group.

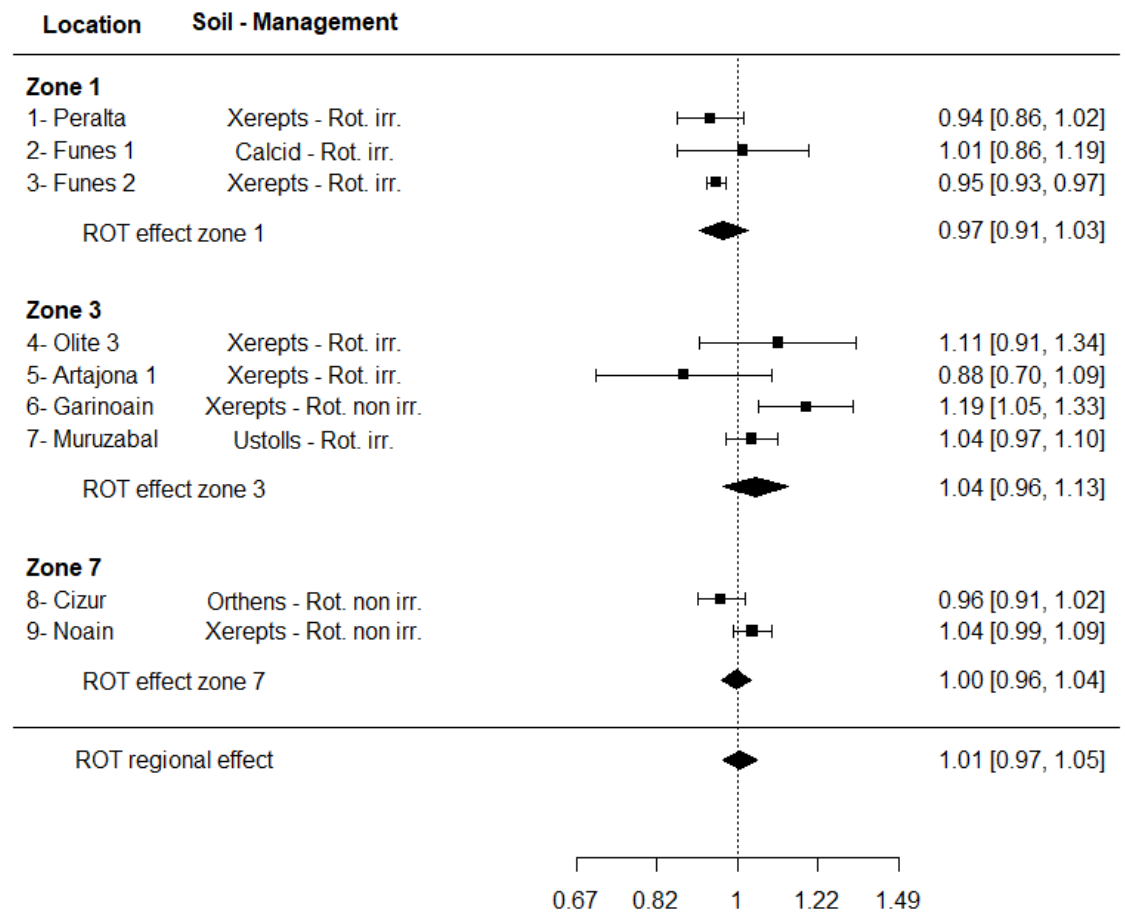

Figure 7. Response ratio (RR) of $\mathrm{BD}(0-30 \mathrm{~cm})$ for the adaptive management strategy of crop rotations (ROT). Zones correspond to those in Figure 1. The effect was considered significant when the 95\% confidence interval $(\mathrm{CI})$ of the RR did not overlap one $(\alpha=0.05)$. Soil and management column includes information about principal soil group and irrigation regime in each group. 


\begin{tabular}{|c|c|c|c|}
\hline Location & Soil - Management & & \\
\hline \multicolumn{4}{|l|}{ Zone 1} \\
\hline $\begin{array}{l}\text { 1- Lerin } \\
\text { 2- Sesma } \\
\text { 3- Carcar } \\
\text { 4- Pitillas } \\
\text { 5- Valtierra 1 } \\
\text { 6- Caparroso } \\
\text { 7- Tudela 1 } \\
\text { 8- Tudela 2 }\end{array}$ & $\begin{array}{l}\text { Xerepts - Xerolls - Duck slurry - Rainfed } \\
\text { Xerolls - Pig slurry - Rainfed } \\
\text { Orthents - Pig slurry - Rainfed } \\
\text { Xerepts - Chicken manure - Annual irr. } \\
\text { Calcid - Sheep manure - Rainfed } \\
\text { Xerepts - Pig slurry - Annual irr. } \\
\text { Fluventic inceptisols and entisols - Sheep manure - Rainfed } \\
\text { Fluventic inceptisols and entisols - Sheep manure - Rainfed }\end{array}$ & 1 & $\begin{array}{l}1.07[0.99,1.15] \\
1.01[0.95,1.08] \\
1.08[1.05,1.11] \\
1.01[0.92,1.11] \\
0.86[0.79,0.93] \\
0.90[0.83,0.99] \\
0.82[0.82,0.82] \\
1.30[1.30,1.30]\end{array}$ \\
\hline ExO effect zone 1 & & 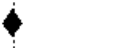 & $1.00[0.97,1.02]$ \\
\hline \multicolumn{4}{|l|}{ Zone 3} \\
\hline $\begin{array}{l}\text { 9- Olite } 1 \\
\text { 10-Olite } 2 \\
\text { 11- Olite } 4 \\
\text { 12- Oloriz }\end{array}$ & $\begin{array}{l}\text { Xerepts - Pig slurry - Rainfed } \\
\text { Xerepts - Pig slurry - Annual irr. } \\
\text { Xerepts - Pig slurry - Annual irr. } \\
\text { Xerepts - Sewage sludge - Annual irr. }\end{array}$ & +1 & $\begin{array}{l}1.10[1.04,1.16] \\
0.94[0.82,1.08] \\
0.79[0.65,0.95] \\
0.81[0.74,0.88]\end{array}$ \\
\hline ExO effect zone 3 & & & $0.90[0.84,0.96]$ \\
\hline \multicolumn{4}{|l|}{ Zone 4} \\
\hline 13- Mendaza & Xerepts with depth limitations - Pig slurry - Rainfed & & $0.91[0.89,0.93]$ \\
\hline \multicolumn{4}{|l|}{ Zone 5} \\
\hline 14- Aibar & Fluventic inceptisols and entisols - Cow manure - Rainfed & -1 & $1.03[1.00,1.07]$ \\
\hline \multicolumn{4}{|l|}{ Zone 7} \\
\hline $\begin{array}{l}\text { 15- Olza } 1 \\
\text { 16- Aranguren }\end{array}$ & $\begin{array}{l}\text { Xerepts - Sewage sludge - Rainfed } \\
\text { Fluventic inceptisols and entisols - Cow-sheep manure - Rainfed }\end{array}$ & $\mapsto-1$ & $\begin{array}{l}1.14[1.07,1.21] \\
0.85[0.82,0.88]\end{array}$ \\
\hline \multicolumn{2}{|l|}{ ExO effect zone 7} & & $0.98[0.95,1.02]$ \\
\hline \multirow[t]{3}{*}{ ExO regional effect } & & 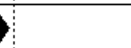 & $0.97[0.95,0.99]$ \\
\hline & 1 & 1 & $\neg$ \\
\hline & 0.67 & 1.22 & 1.49 \\
\hline
\end{tabular}

Figure 8. Response ratio (RR) of BD $(0-30 \mathrm{~cm})$ for the adaptive management strategy of exogenous sources of organic $\mathrm{C}$ addition (ExO). Zones correspond to those in Figure 1. The effect was considered significant when the 95\% confidence interval $(\mathrm{CI})$ of the RR did not overlap one $(\alpha=0.05)$. Soil and management column includes information about principal soil group, organic source applied and irrigation regime in each group.

The strategy of CA was evaluated in 10 groups through the region. The effect of permanent grass cover in permanent crops was evaluated in three groups, where two of them showed a neutral effect and one a negative effect (Figure 6). In the rest of groups where no till was evaluated, four groups were under annual irrigation, and three under rainfed conditions. Within the groups under annual irrigation, the trend was neutral, with only one group with a slightly positive effect. In the case of rainfed groups, two of the three groups showed a negative effect on BD. At zone level, two zones showed a neutral effect, and one zone a negative effect. In the case of the ROT strategy (Figure 7), nine groups were considered, six under irrigation and three without irrigation. One of the groups with irrigation showed a positive effect (lower BD), in one of them under rainfed conditions the effect was negative (higher BD) and the rest of groups showed a neutral effect. In terms of overall zones evaluation, the three zones evaluated in this strategy offered a neutral effect. The strategy ExO (Figure 8) showed a greater variability in the effect than the rest of strategies, so that in seven out of the 16 groups evaluated, a positive effect was observed (lower BD), in four groups the effect was negative (higher BD), and in the rest (five groups) the effect was neutral. Five of the 16 groups within this strategy were under irrigation, where three of them showed a positive effect on BD and two of them neutral. Groups under rainfed conditions showed a more heterogeneous effect (four positive effect, 
three neutral and four negative effect). In the evaluation of zones in which more than one group were included, zone 3 showed a positive effect (lower BD), and in zones 1 and 7 , the effect observed was neutral. IRR strategy (Figure 9) included six groups, three of them under intensive irrigation and three under annual irrigation regime. None of groups under annual irrigation showed a negative negative effect. At zones level, zone 1 showed a neutral effect and zone 4 slightly negative effect (higher BD). At zones level, zone 1 showed a neutral effect and zone 4 a slightly negative effect (higher BD). Finally, the strategy GSS (Figure 10), showed a negative effect (higher BD) in two of the nine groups evaluated. In six groups the effect was neutral and in one of them the effect was positive (lower BD). Considering the zones evaluation in which more than one group were included, zone 1 showed a negative effect, and in zone 10 a neutral effect was observed. At the regional level, CA showed a negative overall effect (higher BD), the strategies ROT, IRR and GSS showed a neutral effect, and only in the case of plots associated to ExO, a slightly positive effect (lower BD) was observed on the RR. Finally, a general observation was that no relationship was observed between the effect of the strategies considered on BD and the effect on SOC (Supplementary Figure S1).

\begin{tabular}{|c|c|c|}
\hline Location & Soil - Management & \\
\hline \multicolumn{3}{|l|}{ Zone 1} \\
\hline 1- M. de Arga 1 & Xerepts - Annual irr. & $1.00[0.94,1.05]$ \\
\hline 2- Santacara 2 & Xerepts - Intensive irr. & $\mapsto 1.11[1.06,1.16]$ \\
\hline 3- Valtierra 3 & Calcid - Intensive irr. & $1.04[0.92,1.16]$ \\
\hline 4- Funes 3 & Calcid - Intensive irr. & $0.92[0.86,0.99]$ \\
\hline IRR effect zone 1 & & $1.01[0.98,1.05]$ \\
\hline \multicolumn{3}{|l|}{ Zone 4} \\
\hline 5- Eneriz 1 & Xerepts - Annual irr. & $0.93[0.89,0.98]$ \\
\hline 6- Eneriz 2 & Xerepts - Annual irr. & $1.00[0.97,1.03]$ \\
\hline IRR effect zone 3 & & $0.97[0.94,0.99]$ \\
\hline \multirow[t]{3}{*}{ IRR regional effect } & & $1.00[0.97,1.03]$ \\
\hline & $\Gamma$ & $\neg$ \\
\hline & 0.82 & 1.11 \\
\hline
\end{tabular}

Figure 9. Response ratio (RR) of $\mathrm{BD}(0-30 \mathrm{~cm})$ for the adaptive management strategy of irrigation (IRR). Zones correspond to those in Figure 1. The effect was considered significant when the 95\% confidence interval $(\mathrm{CI})$ of the RR did not overlap one $(\alpha=0.05)$. Soil and management column includes information about principal soil group and irrigation regime considered in each group.

\subsection{Effect of Management on the Soil Water-Holding Capacity}

Figures 11-15 show the results of the RR effect of the strategies considered on the soil AWHC for each group of plots, together with the overall effect by zone and throughout the region. In this case, an increase in the water retention capacity was considered positive. 


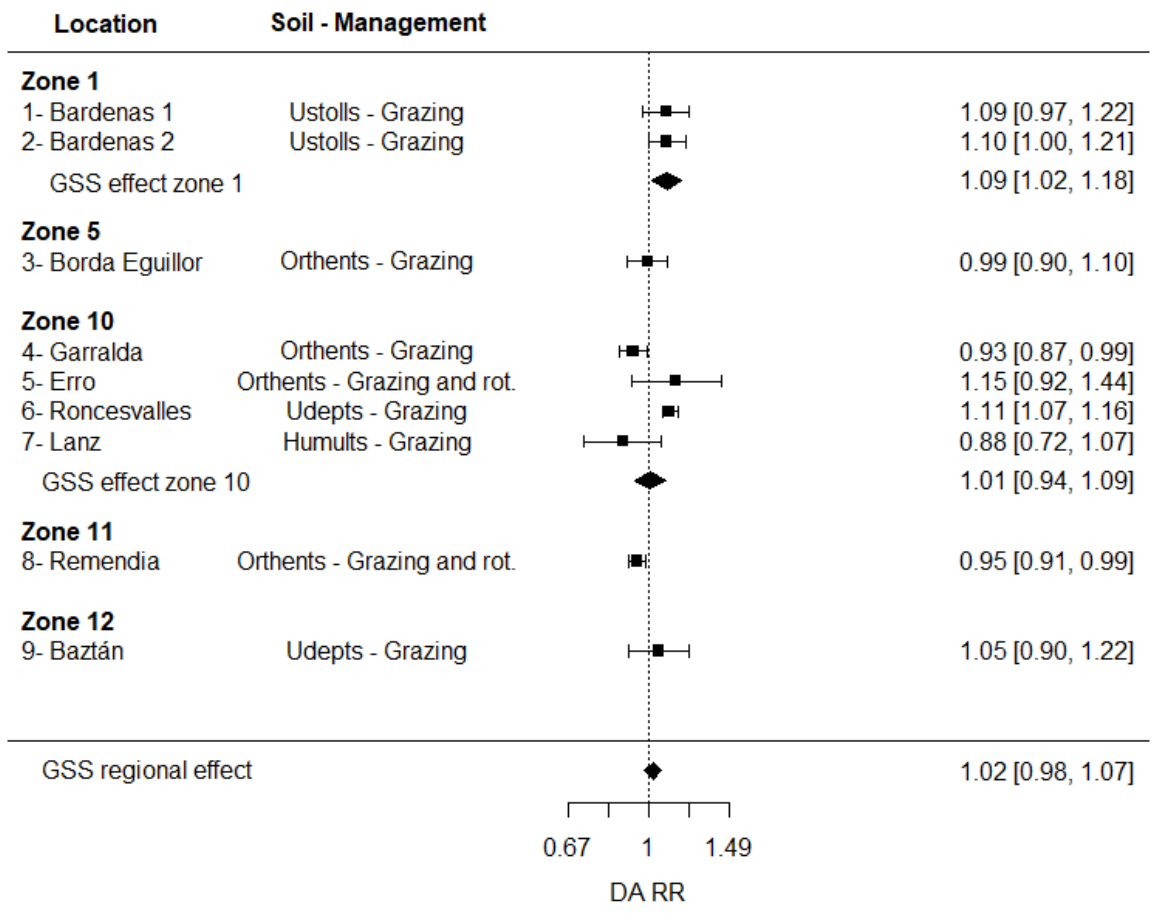

Figure 10. Response ratio (RR) of $\mathrm{BD}(0-30 \mathrm{~cm})$ for the adaptive management strategy of controlled grazing and/or rotation in grasslands (GSS). Zones correspond to those in Figure 1. The effect was considered significant when the $95 \%$ confidence interval (CI) of the RR did not overlap one $(\alpha=0.05)$. Soil and management column includes information about principal soil group and management considered in each group.

In the case of practices linked to CA (Figure 11) where nine groups were considered, no positive effect was observed in any of them. One of the three groups where permanent grass cover in permanent crops was evaluated showed a negative effect on AWHC. In the rest of groups, where no till was evaluated, only one group under rainfed conditions showed a negative effect on AWHC. At the zone level, zone 1 showed more variability in the response, with an overall negative effect. Zones 3 and 7 showed a neutral effect.

The results associated with ROT (Figure 12) showed great variability within groups. Within the groups with irrigation, one of them showed a positive effect and in the others, the effect was neutral. In the case of rainfed groups, the effect was heterogeneous. Considering the evaluation by zones, the 3 zones considered showed a neutral effect. The effect associated to ExO in groups under irrigation showed a positive effect observed in one group in zone 3 whereas the effect was neutral in the other four (Figure 13). The results within the $\mathrm{ExO}$ groups under rainfed conditions showed a great variability in the region, although the effect observed was negative in six of the 11 groups (Figure 13). In the evaluation of zones in which more than one group were included, in the three zones considered the effect observed was neutral (zones 1, 3 and 7). The IRR strategy (Figure 14), in the case of groups with annual irrigation, the results showed 2 groups with a neutral effect on soil AWHC and one with a positive effect. In the case of the 3 groups under intensive irrigation, the results showed a negative effect in two of them, and a positive in the third. In terms of zones, zone 1 showed a neutral effect, and in the case of zone 4 , the effect was positive on this parameter. Finally, the results associated to GSS (Figure 15) showed a neutral effect in six out of the nine groups evaluated. Three groups showed a negative effect on soil AWHC. At the level of zones in which more than one group were included, both zone 1 and 10 showed a neutral effect on this parameter. 


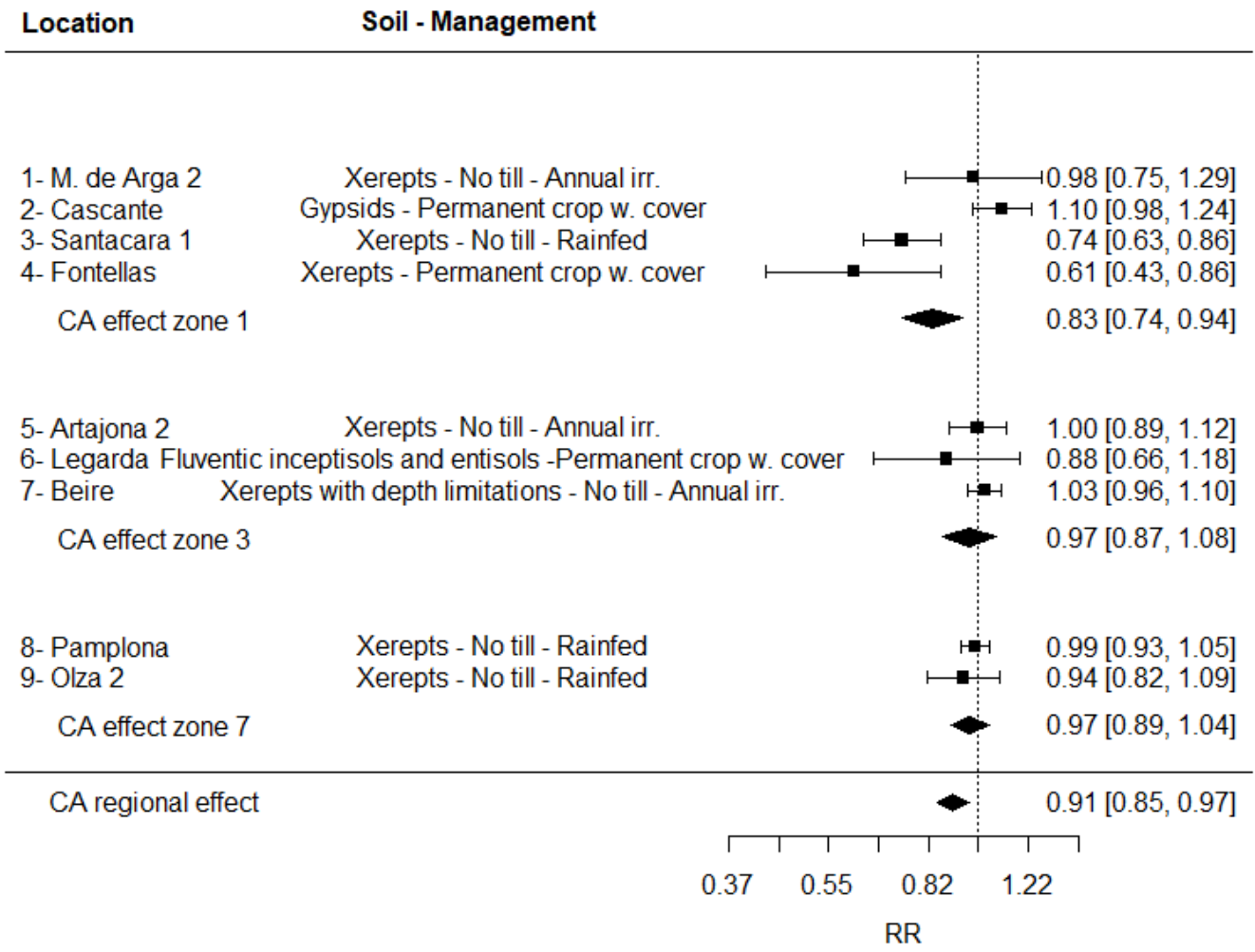

Figure 11. Response ratio (RR) of AWHC $(0-30 \mathrm{~cm})$ for the adaptive management strategy of conservation agriculture (CA). Zones correspond to those in Figure 1. The effect was considered significant when the $95 \%$ confidence interval (CI) of the RR did not overlap one $(\alpha=0.05)$. Soil and management column includes information about principal soil group, strategic management considered and irrigation regime in each group.

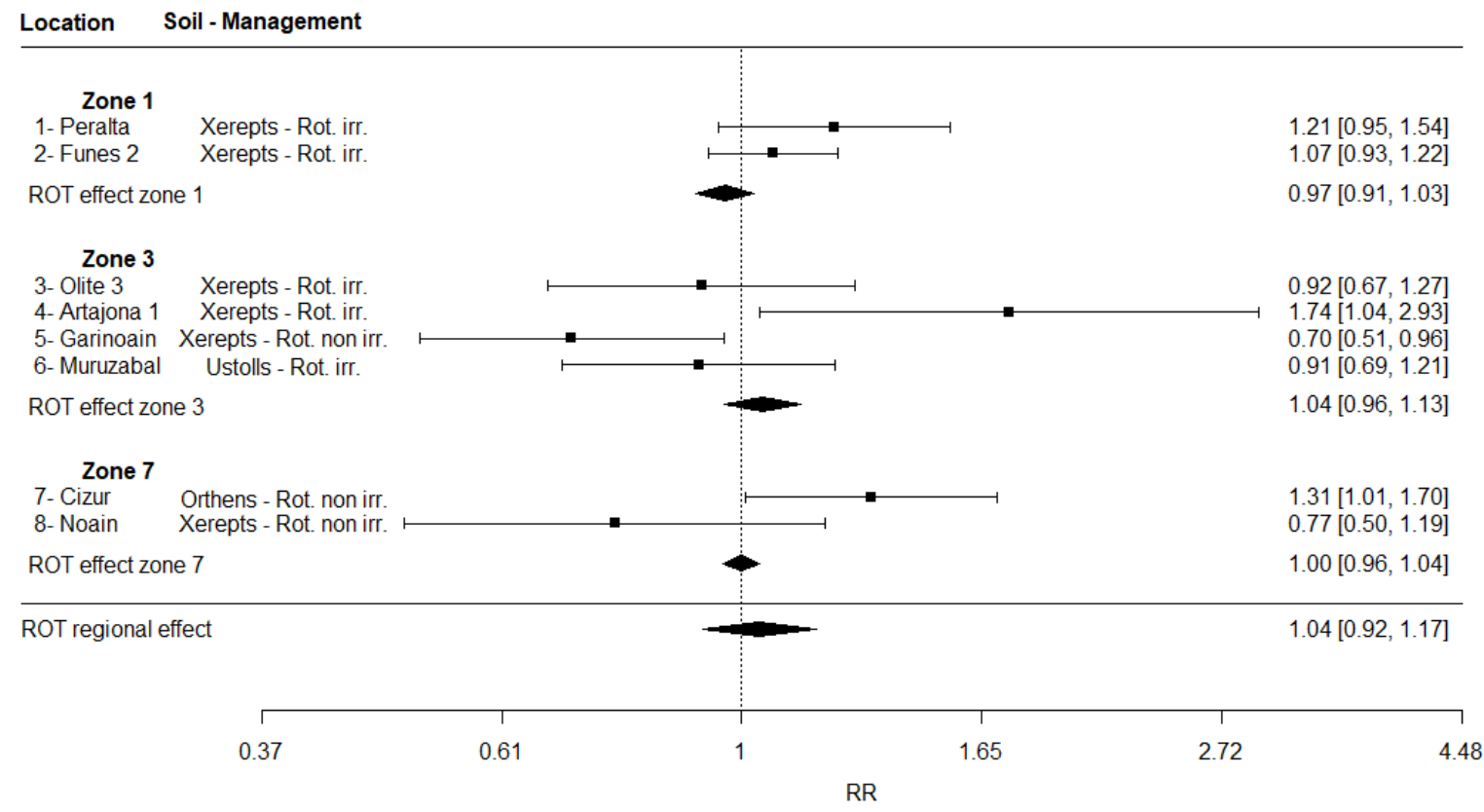

Figure 12. Response ratio (RR) of AWHC $(0-30 \mathrm{~cm})$ for the adaptive management strategy of crop rotations (ROT). Zones correspond to those in Figure 1. The effect was considered significant when the 95\% confidence interval (CI) of the RR did not overlap one $(\alpha=0.05)$. Soil and management column includes information about principal soil group and irrigation regime in each group. 


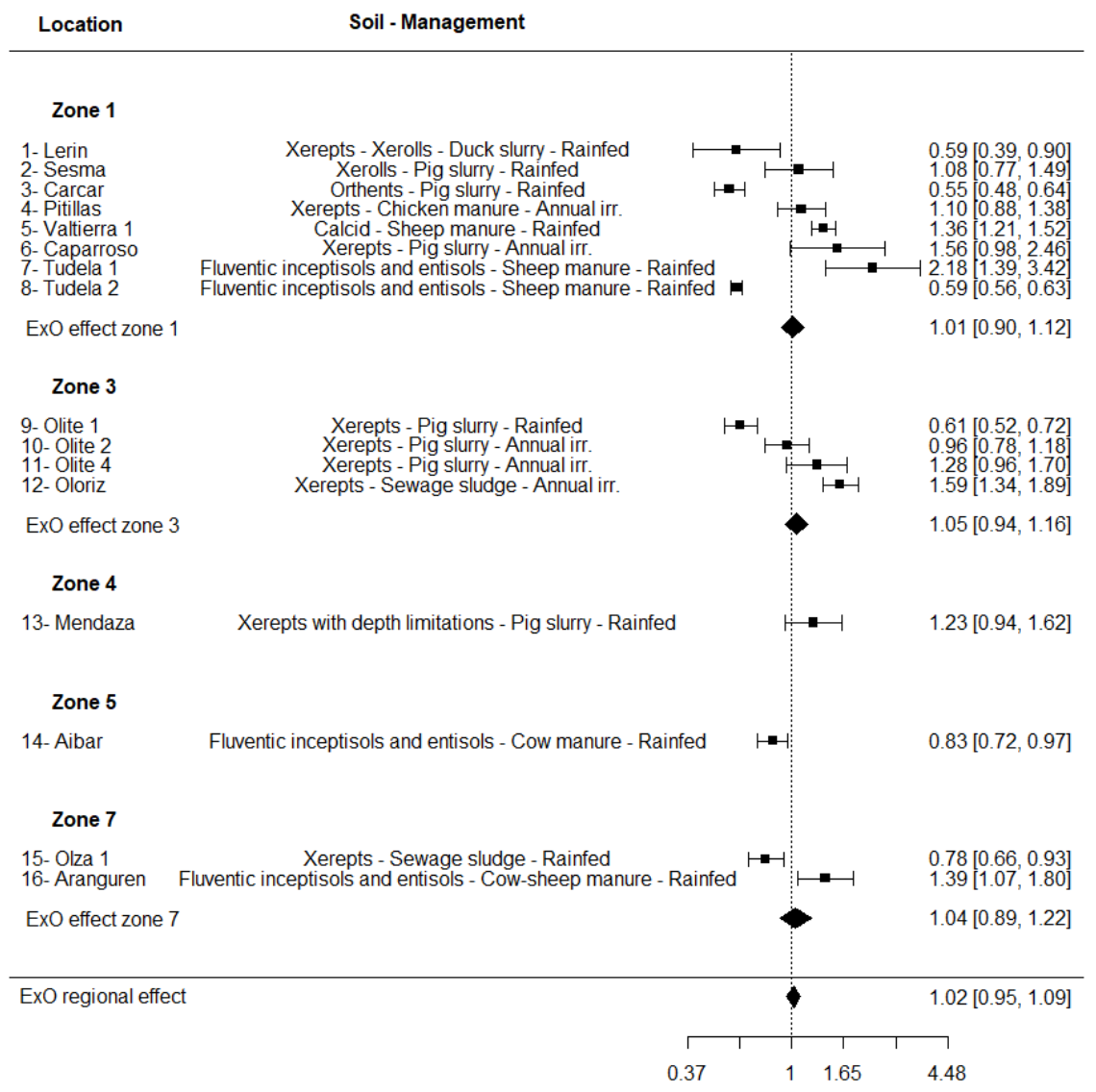

Figure 13. Response ratio (RR) of AWHC $(0-30 \mathrm{~cm})$ for the adaptive management strategy of exogenous sources of organic $\mathrm{C}$ addition (ExO). Zones correspond to those in Figure 1. The effect was considered significant when the $95 \%$ confidence interval (CI) of the RR did not overlap one $(\alpha=0.05)$. Soil and management column includes information about principal soil group, organic source applied and irrigation regime in each group.

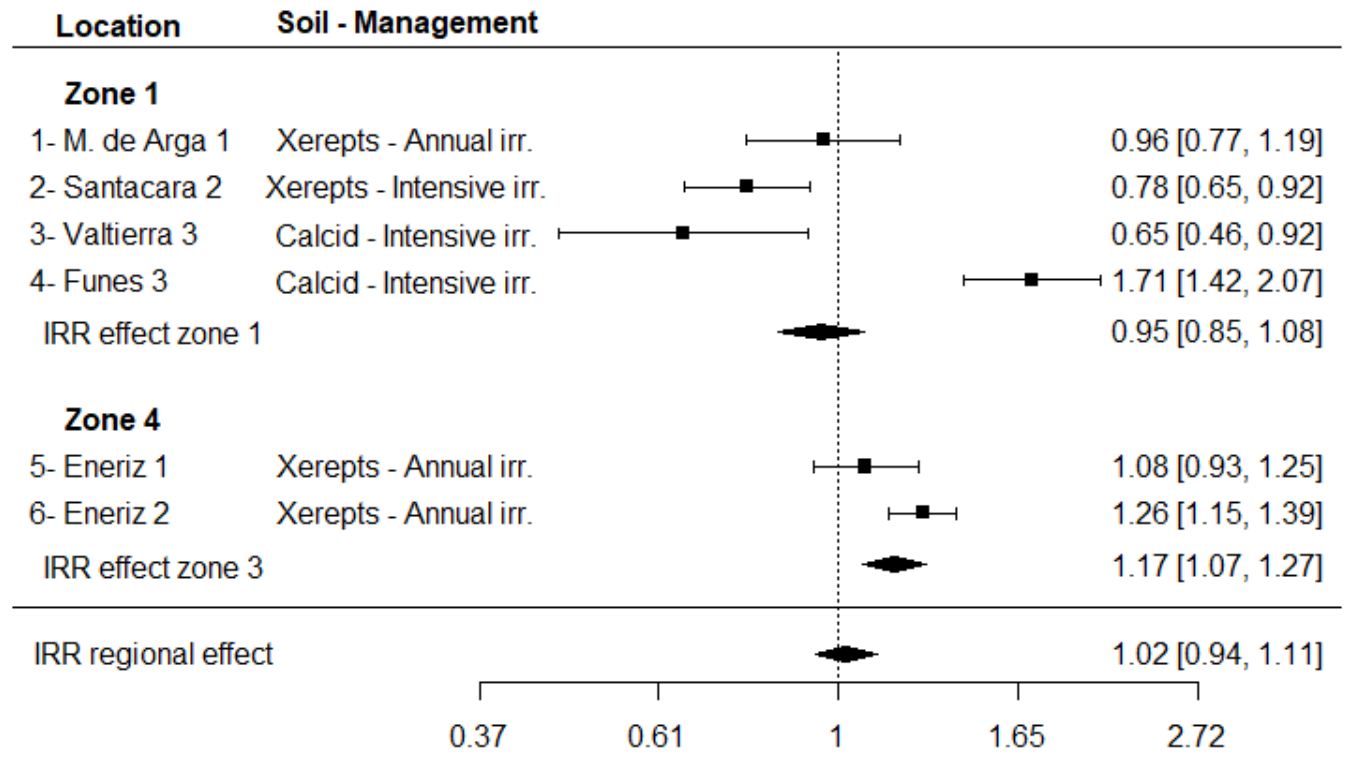

Figure 14. Response ratio (RR) of AWHC $(0-30 \mathrm{~cm})$ for the adaptive management strategy of irrigation (IRR). Zones correspond to those in Figure 1. The effect was considered significant when the $95 \%$ confidence interval (CI) of the RR did not overlap one $(\alpha=0.05)$. Soil and management column includes information about principal soil group and irrigation regime considered in each group. 


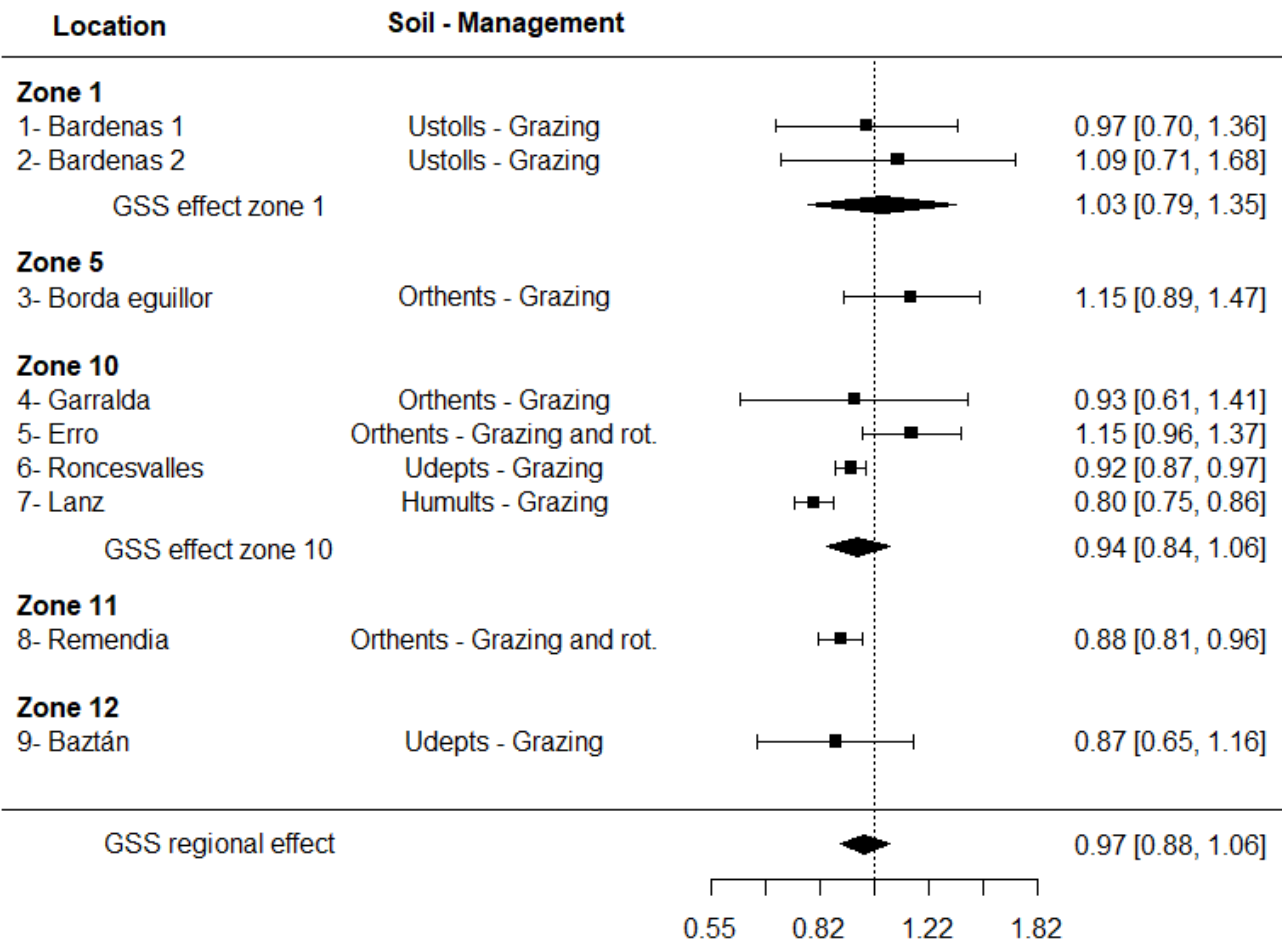

Figure 15. Response ratio (RR) of AWHC $(0-30 \mathrm{~cm})$ for the adaptive management strategy of controlled grazing and/or rotation in grasslands (GSS). Zones correspond to those in Figure 1. The effect was considered significant when the $95 \%$ confidence interval (CI) of the RR did not overlap one $(\alpha=0.05)$. Soil and management column includes information about principal soil group and management considered in each group.

As for $\mathrm{BD}$, no relationship was observed between the effect of the strategies considered on AWHC and the effect on SOC (Supplementary Figure S1).

In terms of the regional evaluation, the observed overall effect associated to the strategies ROT, ExO, IRR and GSS was neutral on soil AWHC, whereas the strategy associated to CA was the only one that showed a slightly overall negative effect.

\section{Discussion}

\subsection{Regional Characteristics}

A first general observation can be made in relation to the great variability found both in $\mathrm{BD}$ and $\mathrm{AWHC}$ in the conventionally-managed fields used as a reference to determine the regional baseline. The source of this variability can be partly explained by the diversity of soils included in the study, belonging to different soil units, and with different SOC stocks (Table 1), in addition to the wide variety of cultivation systems included within the plots under conventional management in this study, from permanent crops such as olive trees, vineyards or pastures, to plots with arable crops with different management intensities.

The relevance of the amount of SOC stored in the topsoil and the soil physical condition at the regional scale became apparent both for BD and AWHC. The areas with managements linked to pastures and grasslands, which had the highest SOC contents in average (Table 2), tended to have the lowest $\mathrm{BD}$ values in the region, especially in areas 10 and 12 . The highest values of AWHC were also observed in zones 10 and 11, associated with grasslands, and were within the range of those observed in similar pasture zones [71]. This has been repeatedly reported in other regions and national-scale studies [72-76], and can be explained by the role of SOC in compensating the possible compaction due to intensive grazing and/or cropping (which were the conventional managements tested in these systems) $[77,78]$. This relationship was reflected in the results of the group associated with pastures in zone 1 (semi-arid), that showed much lower SOC contents (data not shown), 
and displayed AWHC values in line with those observed in cultivated plots in the same zone, and far from the values observed in zones 10 and 11. Greater SOC stocks observed in these zones can be explained by a higher primary productivity because of a moister climate (Table 1), and to the absence of a regular alteration of soil structure by tillage [38]. As for $\mathrm{BD}$, this can be linked to the higher SOC contents observed in these areas associated

$\mathrm{BD}$ and $\mathrm{AWHC}$ values observed in the other zones, mostly associated to cultivation of different crops, were within those observed in agricultural soils in previous studies conducted in the region $[38,48,79,80]$. Intensive tillage, lower SOC contents than grasslands, and differences in the basic physical-chemical characteristics of the soil as a result of intensive agricultural management may explain the differences observed within the areas and soil types present in each zone [76]. Seasonal variations of BD as described by some authors $[63,64]$ can be considered less relevant, as the sampling routine was performed at similar crop stages, corresponding to the end of the growing season or close to harvest.

\subsection{Adaptive Management and Bulk Density}

In relation to the overall effect of the agricultural managements tested in the region on $\mathrm{BD}$, the different strategies evaluated showed a heterogeneous response. Only the strategy ExO showed an overall positive effect on this parameter. ROT, IRR and GSS displayed no clear effect and, in the case of CA, the effect was slightly negative overall.

Greater values of BD than under conventional management, and overall soil compaction, have frequently been associated to the reduction or suppression of tillage with CA [81]. However, such an increment seems not clear, or at least not systematic. For instance, Blanco-Canqui and Ruis [82] suggested that CA can have mixed effects on soil bulk density. Nunes et al. [83], in a meta-analysis carried out from 295 studies located in the USA, did in fact not find differences in BD between different tillage intensities within the topsoil layers. This variability in the response, together with an overall slightly negative effect observed in this study, support these observations of a heterogeneous response. Even so, the negative trend was more evident in the rainfed groups, in line with previous studies developed in experimental plots in the region, which showed increased BD associated with no tillage throughout the profile $[80,84]$. As well as CA is usually associated to a better storage of SOC in the topsoil [85], many authors have emphasized the negative correlation between increases in SOC and soil compaction under CA [83,86,87]. In this case, although CA showed an overall positive regional effect on SOC of around 24\% (Table 2), this increment did not seem to be materialized in an improvement in BD conditions (Figure 6), as it has been observed after the suppression of tillage or the implementation of cover crops, and associated with an increase in SOC and/or root development $[88,89]$. This highlights the need for a better understanding between SOC dynamics and soil physics at the local scale. For instance, CA has been seen to have contrasted effects on soil quality in semi-arid land, depending on the crops rotation strategy accompanying it [90].

The strategy ExO was the only one that resulted in a positive effect on $\mathrm{BD}$ in the network of plots considered in this study, reducing it at least partially, since the results displayed also a high variability. This variability can be related to soil characteristics, management and to the different types of amendments and doses used, as ExO amendments were applied according to crops needs and availability of economically viable organic matter sources. Although this strategy only included five groups under irrigation, none of this groups showed a negative effect, and it was positive in three of them, whereas the response on the rainfed groups was clearly more heterogeneous. The positive effect of ExO in SOC storage has been observed by several authors as responsible for soil (de)compaction [81,91]. This coincides with the observed positive regional effect of ExO on topsoil SOC storage in the studied plots (around 31\%, Table 2). On the other hand, no consistent trend was identified between the types of amendments applied or the different zones evaluated, with an unequal effect throughout the region (Figure 8). The fact that these plots are under conventional soil management including tillage, should also be considered, because of the homogenizing effect of tillage on this parameter. For instance, the sensitivity of BD and 
other physical indicators to manure addition was seen to be relatively small compared with that of tillage after seven years of combined treatment [92].

Considering the ROT strategy assessment, the overall effect observed was neutral throughout the region, although the variability in the response was higher than in CA and $\mathrm{ExO}$ (Figure 7). The decrease in BD normally associated with crop rotations is usually related to an increase in SOC, so that crop rotations driving SOC gains can result in improved BD [44]. In this case, this strategy showed a slightly negative overall regional effect on SOC around $-10 \%$ (Table 2). For Zuber et al. [44], the factors that may determine the direction of the effect include soil texture, previous SOC content, crop and tillage intensity, and the climatic region where the system is located. In this respect, most of the groups considered in this strategy included irrigation, which usually can be associated to increased cropping and tillage intensity compared to rainfed systems. Moreover, plots in all groups considered in this strategy were under conventional soil management including annual tillage.

The latter observation can also explain the overall neutral effect observed in the IRR strategy. Although in this case, the intensity of tillage and the soil homogenization may be counteracting the positive effect on SOC observed associated with this strategy of around $25 \%$ (Table 2). It is also important to note that different irrigation regimes were considered under this strategy: while irrigation of annual crops showed no negative effect on BD within the groups analyzed, in contrast with the intensive irrigation regimes.

Finally, for the management of pastures and grasslands (GSS), our results indicated that this strategy did not significantly change the BD at the depth considered. In general, it has been observed that the trampling action of grazing animals when impacting the soil can increase BD, as well as its mechanical resistance $[93,94]$. These authors agree that the intensity of grazing and the time of the year when it happens are determining factors in this case. Byrnes et al. [93] also included the local environmental conditions associated to the geographical location of grasslands as relevant in their effect on soil condition In this sense, a slight response to the climatic gradient in our region may be appreciated in the results (Figure 10). The two groups of plots located in zone 1 (the most arid one in the study, Table 1), were those with a negative effect on $\mathrm{BD}$, compared to those groups in more humid areas, which displayed no or positive effects of GSS. It has to be noted too that GSS plots located in zone 1 showed no differences in $\mathrm{BD}$ with the cultivated plots in the same area (Figure 10), which highlights the dependence of the response of BD on the scale and location where the soils response to management is studied.

\subsection{Adaptive Management and Available Water-Holding Capacity}

The first general observation when assessing the response of the different strategies on AWHC is that this parameter seemed to respond to soil and crop management, although the effect was highly variable. Four of the strategies considered (ROT, ExO, IRR and GSS) showed an overall neutral effect, although the results within the zones were heterogeneous. CA was the only one strategy that showed a negative overall effect, although the effect observed within zones associated to that strategy tends to be neutral.

In this sense, both components of AWHC, namely soil moisture retention at field capacity and permanent wilting point, are often related to SOC content [95]. In general, soil moisture at field capacity shows a clearer response to SOC, while the response of the soils moisture at wilting point usually is more variable and may depend, in part, on texture [96-98]. Hence, the strategies that favor the increase of SOC should also improve the soil AWHC in those soils where an increment of SOC results in a more favorable effect on soil moisture content at field capacity than at wilting point.

Conservation agriculture is often associated with improved soil physical properties which facilitate water absorption and retention, and therefore, its availability for crops $[83,87]$. However, Blanco-Canqui \& Ruis [82], in a review of 14 studies on the effect of CA on AWHC, observed mixed results. According to these authors, the increase in AWHC observed in some cases can be mainly attributed to the gains in SOC generally 
observed with CA [85]. Previous studies conducted in experimental plots in the region showed an improvement in AWHC associated to no-till, which was attributed not only to higher SOC contents, but also to changes in the size and distribution of the network of pores at the topsoil promoted by crop residue management [38,80]. In this study, however, the effect associated to CA on AWHC within the groups was heterogeneous but globally neutral (Figure 11), and the effect on SOC, although also showed some heterogeneity on the same groups evaluated, was negative and close to zero in zones 3 and 7 in comparison to zone 1, with neutral-positive effect (data not shown). These zones differ mostly in their moisture regime, which is drier in zone 1 than in zones 3 and 7. Crop residues left over the soil in CA provide protection from raindrop impact, reduce flow of surface runoff and may prevent pore sealing and crust formation, increasing the available water to be infiltrate and reducing evapotranspiration [99]. In this line, although some authors suggest that CA may allow for saving irrigation water by improving soil water retention properties (and reducing evapotranspiration) $[100,101]$, no differences on AWHC were observed within groups where this strategy was applied in irrigated conditions (Figure 11).

The results also indicated that the effect of CA seemed more related to the use of permanent soil cover in permanent crops in comparison to no-till in annual crops than to the fact that the agrosystems were rainfed or irrigated (Figure 11). Permanent soil cover showed a higher variability in the response than no-till, although in this case there was a significant improvement in SOC associated to this practice (data not shown). As already discussed in the BD section, cover crops management can affect in a variable sense the physical conditions of these soils, including those related to water retention [89,102]. This highlights the need of on-site evaluation of the effect of CA on soil water retention in the region, contrasting in detail the results of the agricultural fields considered in each case, before making extrapolations at the regional level.

The results associated to ROT strategy on AWHC in this study showed a neutral effect, with a great variability within groups (Figure 12), and a negative effect on SOC of around $-10 \%$ (Table 2). For Indoria et al. [103], the appropriate application of crop rotations can favor the development of micro and macro pores or channels that facilitate the movement and retention of soil water. However, these authors indicated that these positive effects can be modulated by the cropping system and its intensification, and their consequences in the improvement of soil structure, porosity, and SOC content. This is in line with the results found in other studies, in which cross effects were observed both by the type of crops included in the rotation and by the intensity of management $[43,104]$. The variety and intensity of the systems included in this study, which, as mentioned above, were mostly associated with irrigation systems, may be influencing the ROT effect.

In this sense, although IRR showed a neutral effect overall (Figure 14), this strategy showed a diverse response throughout the region. The assessment of this strategy can be directly related in this case to the ROT strategy, since as mentioned, the direction of the effect is determined by the type of crop used, intensity of management and tillage system. As observed on BD assessment, annual irrigation regime showed no negative effect on AWHC within the groups analyzed, contrasting with the results associated to intensive irrigation.

Exogenous applications of organic $\mathrm{C}$ in the soil are also commonly associated to an improvement on soil physical properties, which implies, among other things, an improvement in the retention of available water for crops $[35,81,91]$. This strategy offered indeed the best results in both soil BD and SOC (Figure 8 and Table 2) in this regional study. In terms of AWHC, despite the overall neutral effect observed, the results showed a great variability both within groups, and in terms of the effect direction (Figure 13). The different types and doses of organic amendments applied could explain this heterogeneity, as least partially, but other interfering factors, such as cultivation or tillage, should be considered when evaluating this strategy at a regional level. In this sense, in line to that observed in the $\mathrm{BD}$ assessment, none of five groups considered under irrigation conditions showed negative effects on AWHC. In any case, these contrasting results at regional scale showed 
that there was not a direct relationship between SOC gains and improvements of the soil AWHC in the fields considered in this study (Supplementary Figure S1).

Finally, considering the last strategy, GSS, the results observed in this study showed a neutral effect on AWHC (Figure 15). In this regard, it is known that the effect of trampling by grazing animals can cause soil compaction, decreasing the soil pore space and causing a reduction in infiltration and soil water retention [105-107]. For many authors, the effect of this strategy on soil AWHC depends on the intensity of grazing $[45,108]$, and the geographical location [109].

\subsection{Regional Assessment}

The first remarkable observation at the regional scale was that soil type, as considered in this study, revealed not to be a relevant factor in the evaluation of the impact of the strategies assessed. This could be explained because, although soil types were selected based on their taxonomic characteristics in Soil Taxonomy [58], at the depth considered in this study $(0-30 \mathrm{~cm})$ profiles that differ in their taxonomic classification may have similar characteristics in this profile. In addition, in the same line, since all the soils included in this study were agricultural soils mostly managed for decades to improve their conditions for crop development, this may imply a homogenization of their properties in the upper profile [14].

In relation to the assessment of the soil indicators considered at the regional level, it can be understood that most of the strategies considered here did not show negative effects, and in some cases, some positive effects were observed. It is important to remind that these strategies were assessed because they are already in use in different areas of the region. This suggests that, as observed previously, if they are interesting from the point of view of their profitability, and could have some other positive effects, for instance in SOC storage or controlling or reversing the physical and hydraulic degradation processes, they can be at least considered as able to preserve soil properties and, therefore, soil functions. It should be noted that, this effect, however, is modulated by other factors and should be evaluated in each context.

As observed in other regions [82,83], one of the major concerns of producers in the region regarding the reduction of tillage is the risk of increased soil compaction that may affect seedling emergence, root growth or crop yields. In our study, it was observed that, although the effect at the regional level was negative, it was neutral in most of the groups where CA was evaluated. These considerations, together with the fact that CA can be an effective technique in the promotion of SOC in the upper soil layer (Table 2) and the beneficial effects of crop residues management in CA discussed above, mean that CA may represent a strategy to be considered when assessing climate change adaptation in the region. The latter seems to have a climate- or site-dependent effect, with zone 1 , with the largest agricultural area, showing the best results. This zone also presents some of the worst soils in terms of physical and hydrological degradation, so that, a case-bycase context should be considered in order to improve this soils condition. In relation to permanent crops, although the use of cover crops showed a wide range of response on the physical indicators considered, their contribution in order to control water erosion, reducing both the first impact of rain drops on the soil and water runoff, is also widely accepted [89]. Therefore, their application should be considered a promising one to preserve soil degradation and within climate change adaptation strategies in the region.

An adequate combination of ROT and IRR should be explored in context-specific assessments, considering that, on the one hand, the major climate change threats identified for this region are related to changes in temperatures (average increase and heat waves) and rainfall (scarcity and extreme events), and, on the other hand, they represent very widespread practices in the region. In this sense, a detailed study of the soil water movement and retention, and possible measures to improve them, are essential for developing an efficient irrigation system in the semi-arid part of this region, as in many other regions with limited water resources projections [46]. However, it should be kept in mind that the results 
in terms of AWHC underline the fact that the possible differences in this parameter induced by the different managements tested here can be ephemeral in conventional cultivation practices [110].

The variability of results associated to the ExO strategy on BD and AWHC suggest that factors as soil characteristics and types of amendments and doses, together with the soil management system, should be taken into account when evaluating this strategy at the regional level. Even so, it represents a strategy to be considered when evaluating both soil degradation control strategies and regional adaptation to climate change, considering, additionally, that presents the best results in terms of SOC promotion. It should also be noted that it allows for the redistribution of surpluses from intensive animal farms or water treatment plants. In this respect, other factors such as the geographical location of the source, their availability and their economic viability should be also considered. Last observation is that most of the groups considered within this strategy were on rainfed conditions, also within zone 1 where irrigation is more extended. This is especially interesting considering that the groups under irrigation conditions reported interesting results, at least in terms of BD.

The results associated with the GSS strategy in relation to BD and AWHC showed a variable effect across the region, where the climate gradient seemed to be a factor, at least in BD. The site-specific factors related to each geographical location appear to be relevant to assess the potential for adaptation to climate change in the region associated with this strategy [93]. In this sense, the zones where this management was more extended, in the North of the region, showed the best results (above average) in terms of physical and hydrological soil degradation.

The observed variability in terms of the adoption and effectiveness of the five strategies tested in this region also suggests that one strategy alone might be not enough to globally improve the soil physical condition. In this sense, some authors have proposed the combination of measures such as irrigation [101,111] with cover crops and/or animal manure application [82], as more effective for instance to improve the potential of no-till in order to enhance the physical properties of the soil and guarantee profitable yields [112]. Priori et al. [89] also proposed a combination of cover crops with the use of proper organic amendments, subsoiling techniques as well as use of biological inoculants in degraded areas of tree crops, in order to couple their positive effect. For these authors, the best strategy must be not only site-specific, but also adapted to the ecosystem functions to be improved.

\section{Conclusions}

The aim of this study was to evaluate the effectiveness of different agricultural adaptive strategies considered in the framework of the regional climate change roadmap in the region of Navarre (Spain) [49] and Nadapta LIFE project in order to control and reverse soil physical degradation and agrosystems vulnerability to climate change. For that purpose, soil indicators associated to soil compaction and water retention were monitored through a network of plot within the region. Both physical parameters considered, BD and AWHC seemed to respond to soil and crop management, although the effect was highly variable.

Although the potential benefits associated with CA, both in cultivated plots and in permanent crops, suggest that it can be of interest for controlling soil degradation processes, its effect on the physical parameters considered was heterogeneous, and not directly related to gains in SOC. The combination of ROT and IRR strategies seemed promising for improving the adaptability of agrosystems in the semi-arid part of this region. ExO should be also considered as a strategy within a framework of climate change regional adaptation, as it displayed a generally positive effect on BD and AWHC, and it may allow for the redistribution of surpluses from intensive animal farms or water treatment plants, in line with the Circular Economy Action Plan from the European Green Deal [113]. Site-specific environmental factors appeared to be relevant to assess the potential of the GSS strategy. 
The observed variability in terms of the adoption and effectiveness of the five strategies tested in this region seemed to be modulated by geographical and management factors, which should therefore be evaluated in each context. This highlights the need to understand the complexity of interrelationships between different aspects of soil management and soil properties at a regional scale, and indicates that more detailed research is needed to assess soil vulnerability and the possible adaptability potential of agricultural management. Moving towards a diagnosis and advice at farm level seems necessary in this sense.

Supplementary Materials: The following are available online at https: / www.mdpi.com/2073-4 395/11/3/607/s1, Figure S1: Response ratios of BD (a) and AWHC (b) vs. those observed for soil organic $\mathrm{C}$ stock. The five different strategies are represented by colour: conservation agriculture (CA), management of exogenous sources of organic $\mathrm{C}(\mathrm{ExO})$, crop rotations (ROT), irrigation (IRR) and optimized grasslands management (GSS).

Author Contributions: Conceptualization, I.V., R.A. and L.O.; methodology, R.A., A.R.-S., F.J.A. and I.V.; software, R.A. and A.R.-S.; formal analysis, R.A. and I.V.; investigation, L.O., A.R.-S., R.A., I.V. and A.E.; writing—original draft preparation, R.A., I.V.; writing—review and editing, R.A., A.R.-S., L.O., F.J.A., A.E., I.d.S. and I.V.; supervision, I.V. and L.O.; project administration, I.V.; funding acquisition, I.V., L.O. All authors have read and agreed to the published version of the manuscript.

Funding: This research was funded by the European Commission LIFE program (Project LIFE Nadapta, LIFE 16 IPC/ES/000001). Rodrigo Antón was awarded a pre-doctoral fellowship by Universidad Pública de Navarra.

Institutional Review Board Statement: Not applicable.

Informed Consent Statement: Not applicable.

Data Availability Statement: The data presented in this study are available on request from the corresponding author. The data are not publicly available due to their belonging to a multistakeholder project.

Acknowledgments: We thank Javier Eslava (Government of Navarre) for assistance in soil characterization and cartographic information. Iñigo Ayechu (INTIA) and Conchi González (UPNA) are thanked for field and laboratory assistance.

Conflicts of Interest: The authors declare no conflict of interest.

\section{References}

1. Jia, G.; Shevliakova, E.; Artaxo, P.; De Noblet-Decoudré, N.; Houghton, R.; House, J.; Kitajima, K.; Lennard, C.; Popp, A.; Sirin, A.; et al. Climate change and land. Chapter 2: Land-Climate Interactions. IPCC Spec. Rep. Glob. Warm. 1.5 ${ }^{\circ} \mathrm{C} \mathrm{2019,1-186.}$

2. IPCC. IPCC, 2014: Summary for policymakers. In Climate Change 2014: Impacts, Adaptation, and Vulnerability. Part A: Global and Sectoral Aspects. Contribution of Working Group II to the Fifth Assessment Report of the Intergovernmental Panel on Climate Change; Field, C.B., Barros, D.J., Dokken, K.J., Mach, M.D., Mastrandrea, T.E., Bilir, M., Chatterjee, K.L., Ebi, Y.O., Estrada, R.C., Genova, B., et al., Eds.; Ambridge University Press: Cambridge, UK; New York, NY, USA, 2014; p. 32.

3. Rounsevell, M.D.A.; Evans, S.P.; Bullock, P. Climate change and agricultural soils: Impacts and adaptation. Clim. Chang. 1999, 43, 683-709. [CrossRef]

4. Adhikari, K.; Hartemink, A.E. Linking soils to ecosystem services-A global review. Geoderma 2016, 262, 101-111. [CrossRef]

5. Blum, W.E.H. Functions of soil for society and the environment. Rev. Environ. Sci. Biotechnol. 2005, 4, 75-79. [CrossRef]

6. CEC. Communication From the Commission to the Council, the European Parliament, the European Economic and Social Committee, and the Committee of the Regions: A Mid-Term Assessment of Implementing the EC Biodiversity Action Plan. J. Int. Wildl. Law Policy 2009, 12, 108-120. [CrossRef]

7. Bouma, J. Soil science contributions towards Sustainable Development Goals and their implementation: Linking soil functions with ecosystem services. J. Plant Nutr. Soil Sci. 2014, 177, 111-120. [CrossRef]

8. Allen, D.E.; Singh, B.P.; Dalal, R.C. Soil Health Indicators Under Climate Change: A Review of Current Knowledge. In Soil Health and Climate Change; Singh, B.P., Cowie, A., Chan, K., Eds.; Springer: Berlin/Heidelberg, Germany, 2011; pp. 260-261; ISBN 9783642202568 .

9. French, S.; Levy-Booth, D.; Samarajeewa, A.; Shannon, K.E.; Smith, J.; Trevors, J.T. Elevated temperatures and carbon dioxide concentrations: Effects on selected microbial activities in temperate agricultural soils. World J. Microbiol. Biotechnol. 2009, 25, 1887-1900. [CrossRef] 
10. Handmer, J.Y.; Honda, Z.W.; Kundzewicz, N.; Arnell, G.; Benito, J.; Hatfield, I.F.; Mohamed, P.; Peduzzi, S.; Wu, B. Changes in Impacts of Climate Extremes: Human Systems and Ecosystems. In Managing the Risks of Extreme Events and Disasters to Advance Climate Change Adaptation; Field, C.B., Barros, T.F., Stocker, D., Qin, D.J., Dokken, K.L., Ebi, M.D., Mastrandrea, K.J., Mach, G.-K., Plattner, S.K., Allen, M., et al., Eds.; Cambridge University Press: Cambridge, UK, 2012; pp. 231-290.

11. Hatfield, J.L.; Boote, K.J.; Kimball, B.A.; Ziska, L.H.; Izaurralde, R.C.; Ort, D.; Thomson, A.M.; Wolfe, D. Climate impacts on agriculture: Implications for crop production. Agron. J. 2011, 103, 351-370. [CrossRef]

12. Porter, J.R.; Xie, L.; Challinor, A.J.; Cochrane, K.; Howden, S.M.; Iqbal, M.M.; Lobell, D.B.; Travasso, M.I.; Aggarwal, P.; Hakala, K.; et al. Food security and food production systems. Manag. Risks Extrem. Events Disasters Adv. Clim. Chang. Adapt. A Spec. Rep. Work. Groups I II Intergov. Panel Clim. Chang. 2015, 485-534. [CrossRef]

13. Horel, Á.; Tóth, E.; Gelybó, G.; Kása, I.; Bakacsi, Z.; Farkas, C. Effects of Land Use and Management on Soil Hydraulic Properties. Open Geosci. 2015, 7, 1442-1454. [CrossRef]

14. Kuzyakov, Y.; Zamanian, K. Reviews and syntheses: Agropedogenesis-Humankind as the sixth soil-forming factor and attractors of agricultural soil degradation. Biogeosciences 2019, 16, 4783-4803. [CrossRef]

15. Li, H.; Yao, Y.; Zhang, X.; Zhu, H.; Wei, X. Changes in soil physical and hydraulic properties following the conversion of forest to cropland in the black soil region of Northeast China. Catena 2021, 198, 104986. [CrossRef]

16. Panagos, P.; Borrelli, P.; Meusburger, K.; Alewell, C.; Lugato, E.; Montanarella, L. Estimating the soil erosion cover-management factor at the European scale. Land Use Policy 2015, 48, 38-50. [CrossRef]

17. Virto, I.; Imaz, M.J.; Fernández-Ugalde, O.; Gartzia-Bengoetxea, N.; Enrique, A.; Bescansa, P. Soil degradation and soil quality in Western Europe: Current situation and future perspectives. Sustainability 2015, 7, 313-365. [CrossRef]

18. Chenu, C.; Angers, D.A.; Barré, P.; Derrien, D.; Arrouays, D.; Balesdent, J. Increasing organic stocks in agricultural soils: Knowledge gaps and potential innovations. Soil Tillage Res. 2019, 188, 41-52. [CrossRef]

19. del Pozo, A.; Brunel-Saldias, N.; Engler, A.; Ortega-Farias, S.; Acevedo-Opazo, C.; Lobos, G.A.; Jara-Rojas, R.; Molina-Montenegro, M.A. Climate change impacts and adaptation strategies of agriculture in Mediterranean-climate regions (MCRs). Sustainability 2019, 11, 2769. [CrossRef]

20. Costantini, E.A.C.; Antichi, D.; Almagro, M.; Hedlund, K.; Sarno, G.; Virto, I. Local adaptation strategies to increase or maintain soil organic carbon content under arable farming in Europe: Inspirational ideas for setting operational groups within the European innovation partnership. J. Rural Stud. 2020, 79, 102-115. [CrossRef]

21. IPCC. Summary for Policymaker. In Climate Change and Land: An IPCC Special Report on Climate Change, Desertification, Land Degradation, Sustainable Land Management, Food Security, and Greenhouse gas Fluxes in Terrestrial Ecosystems; Shukla, P.R., Skea, J., Buendia, E.C., Masson-Delmotte, V., Pörtner, H.-O., Roberts, D.C., Zhai, P., Slade, R., Connors, S., van Diemen, R., et al., Eds.; In press; 2019; pp. 423-449. ISBN 9781784710644.

22. European Commission. How the Future Cap Will Contribute to the eu Green Deal (2020); European Commission: Brussels, Belgium, 2020.

23. European Commission. Staff Commissions Staff Working Document: Analysis of Links between Cap Reform and Green Deal SWD(2020) 93 Final; European Commission: Brussels, Belgium, 2020.

24. Panagos, P.; Ballabio, C.; Poesen, J.; Lugato, E.; Scarpa, S.; Montanarella, L.; Borrelli, P. A soil erosion indicator for supporting agricultural, environmental and climate policies in the European union. Remote Sens. 2020, 12, 1365. [CrossRef]

25. Alliance Environnement. Evaluation Support Study on the Impact of the CAP on Sustainable Management of the Soil. Final Report; European Commission: Brussels, Belgium, 2020; ISBN 9789276214113.

26. Andrews, S.S.; Karlen, D.L.; Cambardella, C.A. The soil management assessment framework: A quantitative soil quality evaluation method. Soil Sci. Soc. Am. J. 2004, 68, 1945-1962. [CrossRef]

27. Doran, J.; Parkin, T. Quantitative indicators of soil Quality: A minimum data set. In Methods forassessing Soil Quality; Wiley Online Library: Hoboken, NJ, USA, 1996; pp. 25-37.

28. Drobnik, T.; Greiner, L.; Keller, A.; Grêt-Regamey, A. Soil quality indicators-From soil functions to ecosystem services. Ecol. Indic. 2018, 94, 151-169. [CrossRef]

29. Rinot, O.; Levy, G.J.; Steinberger, Y.; Svoray, T.; Eshel, G. Soil health assessment: A critical review of current methodologies and a proposed new approach. Sci. Total Environ. 2019, 648, 1484-1491. [CrossRef] [PubMed]

30. Paustian, K.; Collier, S.; Baldock, J.; Burgess, R.; Creque, J.; DeLonge, M.; Dungait, J.; Ellert, B.; Frank, S.; Goddard, T.; et al. Quantifying carbon for agricultural soil management: From the current status toward a global soil information system. Carbon Manag. 2019, 10, 567-587. [CrossRef]

31. Dignac, M.F.; Derrien, D.; Barré, P.; Barot, S.; Cécillon, L.; Chenu, C.; Chevallier, T.; Freschet, G.T.; Garnier, P.; Guenet, B.; et al. Increasing soil carbon storage: Mechanisms, effects of agricultural practices and proxies. A review. Agron. Sustain. Dev. 2017, 37. [CrossRef]

32. Soussana, J.F.; Lutfalla, S.; Ehrhardt, F.; Rosenstock, T.; Lamanna, C.; Havlík, P.; Richards, M.; Wollenberg, E.; Chotte, J.L.; Torquebiau, E.; et al. Matching policy and science: Rationale for the '4 per 1000-Soils for food security and climate' initiative. Soil Tillage Res. 2019, 188, 3-15. [CrossRef]

33. Rumpel, C.; Amiraslani, F.; Chenu, C.; Garcia Cardenas, M.; Kaonga, M.; Koutika, L.-S.; Ladha, J.; Madari, B.; Shirato, Y.; Smith, P.; et al. The 4p1000 initiative: Opportunities, limitations and challenges for implementing soil organic carbon sequestration as a sustainable development strategy. Ambio 2020, 49, 350-360. [CrossRef] [PubMed] 
34. Bünemann, E.K.; Bongiorno, G.; Bai, Z.; Creamer, R.E.; De Deyn, G.; de Goede, R.; Fleskens, L.; Geissen, V.; Kuyper, T.W.; Mäder, P.; et al. Soil quality-A critical review. Soil Biol. Biochem. 2018, 120, 105-125. [CrossRef]

35. Blanco-Canqui, H.; Hergert, G.W.; Nielsen, R.A. Cattle Manure Application Reduces Soil Compactibility and Increases Water Retention after 71 Years. Soil Sci. Soc. Am. J. 2015, 79, 212-223. [CrossRef]

36. Williams, A.; Hedlund, K. Indicators of soil ecosystem services in conventional and organic arable fields along a gradient of landscape heterogeneity in southern Sweden. Appl. Soil Ecol. 2013, 65, 1-7. [CrossRef]

37. Yu, G.H.; Chen, C.M.; He, X.H.; Zhang, X.Z.; Li, L.N. Unexpected bulk density and microstructures response to long-term pig manure application in a Ferralic Cambisol Soil: Implications for rebuilding a healthy soil. Soil Tillage Res. 2020, 203. [CrossRef]

38. Bescansa, P.; Imaz, M.J.; Virto, I.; Enrique, A.; Hoogmoed, W.B. Soil water retention as affected by tillage and residue management in semiarid Spain. Soil Tillage Res. 2006, 87, 19-27. [CrossRef]

39. Mondal, S.; Chakraborty, D.; Das, T.K.; Shrivastava, M.; Mishra, A.K.; Bandyopadhyay, K.K.; Aggarwal, P.; Chaudhari, S.K. Conservation agriculture had a strong impact on the sub-surface soil strength and root growth in wheat after a 7-year transition period. Soil Tillage Res. 2019, 195. [CrossRef]

40. Skaalsveen, K.; Ingram, J.; Clarke, L.E. The effect of no-till farming on the soil functions of water purification and retention in north-western Europe: A literature review. Soil Tillage Res. 2019, 189, 98-109. [CrossRef]

41. Li, Y.; Li, Z.; Cui, S.; Jagadamma, S.; Zhang, Q. Residue retention and minimum tillage improve physical environment of the soil in croplands: A global meta-analysis. Soil Tillage Res. 2019, 194. [CrossRef]

42. Alhameid, A.; Singh, J.; Sekaran, U.; Ozlu, E.; Kumar, S.; Singh, S. Crop rotational diversity impacts soil physical and hydrological properties under long-term no- and conventional-till soils. Soil Res. 2019, 58, 84-94. [CrossRef]

43. Kazula, M.J.; Lauer, J.G.; Arriaga, F.J. Crop rotation effect on selected physical and chemical properties of Wisconsin soils. J. Soil Water Conserv. 2017, 72, 553-563. [CrossRef]

44. Zuber, S.M.; Behnke, G.D.; Nafziger, E.D.; Villamil, M.B. Crop rotation and tillage effects on soil physical and chemical properties in Illinois. Agron. J. 2015, 107, 971-978. [CrossRef]

45. Teague, W.R.; Dowhower, S.L.; Baker, S.A.; Haile, N.; DeLaune, P.B.; Conover, D.M. Grazing management impacts on vegetation, soil biota and soil chemical, physical and hydrological properties in tall grass prairie. Agric. Ecosyst. Environ. 2011, 141, 310-322. [CrossRef]

46. Al-Rumikhani, Y.A. Effect of crop sequence, soil sample location and depth on soil water holding capacity under center pivot irrigation. Agric. Water Manag. 2002, 55, 93-104. [CrossRef]

47. Reynolds, W.D.; Bowman, B.T.; Drury, C.F.; Tan, C.S.; Lu, X. Indicators of good soil physical quality: Density and storage parameters. Geoderma 2002, 110, 131-146. [CrossRef]

48. Antón, R.; Virto, I.; Gonzalez, J.; Hernandez, I.; Enrique, A.; Bescansa, P.; Arias, N.; Orcaray, L.; Campillo, R. Extension of irrigation in semi-arid regions: What challenges for soil security? Perspectives from a regional-scale project in Navarre (Spain). In Global Soil Security. Towards More Science-Society Interfaces; de Forges, A.R., Carré, F., McBratney, A.B., Johan Bouma, D.A., Eds.; Taylor \& Francis Group: London, UK, 2019; pp. 79-87. ISBN 978-1-315-10707-3.

49. Gobierno de Navarra. Hoja de Ruta Cambio Climático de Navarra (HCCN) 2017-2030-2050; Gobierno de Navarra: Pamplona, Spain, 2017.

50. European Commission. An EU Strategy on Adaptation to Climate Change. COM(2013) 216 Final; European Commission: Brussels, Belgium, 2013.

51. Paustian, K.; Lehmann, J.; Ogle, S.; Reay, D.; Robertson, G.P.; Smith, P. Climate-smart soils. Nature 2016, 532, 49-57. [CrossRef]

52. FAO. Cllimate-Smart Agriculture. Sourcebook; FAO: Rome, Italy, 2013; ISBN 9789251077207.

53. Pejenaute Goñi, J.M. Navarra. Geografía; Nafarroako, G., de Navarra, G., Eds.; Horizonte: Pamplona, Spain, 2017.

54. Gobierno de Navarra. Meteorología y climatología de Navarra (Metherology and Climatology of Navarre). Available online: http:/ / meteo.navarra.es/estaciones/mapadeestaciones.cfm (accessed on 11 November 2020).

55. Peralta, J.; Biurrum, I.; García-Mijangos, I.; Remón, J.L.; Olano, J.M.; López, M.L.; Loidi, J.; Campos, J.A. Manual de Hábitats de Navarra; Gobierno de Navarra: Pamplona, Spain, 2013; ISBN 9788423533503.

56. Rivas-Martinez, S. Notions on dynamic-catenal phytosociology as a basis of landscape science. Plant Biosyst. 2005, 139, 135-144. [CrossRef]

57. Papadakis, J. Agricultural Geography of the World [Climate, Growth Rate and Rhythm, Vegetation, Soils, Crops, Agricultural Regions]; CAB Direct: Buenos Aires, Argentina, 1952.

58. Soil Survey Staff. Keys to Soil Taxonomy; USDA: Madison, WI, USA, 2014; Volume 12, ISBN 016085427X.

59. Tugel, A.J.; Wills, S.A.; Herrick, J.E. Soil Change Guide: Procedures for Soil Survey and Resource Inventory, Version 1.1.; USDA, Natural Resources Conservation Service, National Soil Survey Center: Lincoln, NE, USA, 2008.

60. Wiesmeier, M.; Hübner, R.; Barthold, F.; Spörlein, P.; Geuß, U.; Hangen, E.; Reischl, A.; Schilling, B.; von Lützow, M.; KögelKnabner, I. Amount, distribution and driving factors of soil organic carbon and nitrogen in cropland and grassland soils of southeast Germany (Bavaria). Agric. Ecosyst. Environ. 2013, 176, 39-52. [CrossRef]

61. IDENA (Infraestructura de Datos Espaciales de Navarra). Available online: https://idena.navarra.es/Portal/Descargar (accessed on 13 May 2020).

62. Stolbovoy, V.; Montanarella, L.; Jones, A.; Gallego, J. Soil Sampling Protocol to Certify the Changes of Organic carbon Stock in Mineral soil of the European Union. Version 2; Office for Official Publications of the European Communities: Luxembourg, 2007. 
63. Franzluebbers, A.J.; Hons, F.M.; Zuberer, D.A. Tillage-induced seasonal changes in soil physical properties affecting soil CO2 evolution under intensive cropping. Soil Tillage Res. 1995, 34, 41-60. [CrossRef]

64. Logsdon, S.D.; Karlen, D.L. Bulk density as a soil quality indicator during conversion to no-tillage. Soil Tillage Res. 2004, 78, 143-149. [CrossRef]

65. Richards, L.; Weaver, L. Moisture retention by some irrigated soils as related to soil moisture tension. J. Agric. Res. 1944, 69, 215-234.

66. Dirksen, C. Soil Physics Measurements; Catena Verlag: Reiskirchen, Germany, 1999.

67. Targulian, V.O.; Krasilnikov, P.V. Soil system and pedogenic processes: Self-organization, time scales, and environmental significance. Catena 2007, 71, 373-381. [CrossRef]

68. Hedges, L.V.; Gurevitch, J.; Curtis, P.S. The meta-analysis of response-ratios in experimental ecology. Ecology 1999, 80, 1150-1156. [CrossRef]

69. Viechtbauer, W. Conducting meta-analyses in R with the metafor. J. Stat. Softw. 2010, 36, 1-48. [CrossRef]

70. Batey, T. Soil compaction and soil management-A review. Soil Use Manag. 2009, 25, 335-345. [CrossRef]

71. Girona-García, A.; Badía-Villas, D.; Martí-Dalmau, C.; Ortiz-Perpiñá, O.; Mora, J.L.; Armas-Herrera, C.M. Effects of prescribed fire for pasture management on soil organic matter and biological properties: A 1-year study case in the Central Pyrenees. Sci. Total Environ. 2018, 618, 1079-1087. [CrossRef]

72. Ammann, C.; Spirig, C.; Leifeld, J.; Neftel, A. Assessment of the nitrogen and carbon budget of two managed temperate grassland fields. Agric. Ecosyst. Environ. 2009, 133, 150-162. [CrossRef]

73. Lasanta, T.; Sánchez-Navarrete, P.; Medrano-Moreno, L.M.; Khorchani, M.; Nadal-Romero, E. Soil quality and soil organic carbon storage in abandoned agricultural lands: Effects of revegetation processes in a Mediterranean mid-mountain area. Land Degrad. Dev. 2020, 1-16. [CrossRef]

74. Peco, B.; Navarro, E.; Carmona, C.P.; Medina, N.G.; Marques, M.J. Effects of grazing abandonment on soil multifunctionality: The role of plant functional traits. Agric. Ecosyst. Environ. 2017, 249, 215-225. [CrossRef]

75. Rodríguez Martín, J.A.; Álvaro-Fuentes, J.; Gonzalo, J.; Gil, C.; Ramos-Miras, J.J.; Grau Corbí, J.M.; Boluda, R. Assessment of the soil organic carbon stock in Spain. Geoderma 2016, 264, 117-125. [CrossRef]

76. Tang, S.; Guo, J.; Li, S.; Li, J.; Xie, S.; Zhai, X.; Wang, C.; Zhang, Y.; Wang, K. Synthesis of soil carbon losses in response to conversion of grassland to agriculture land. Soil Tillage Res. 2019, 185, 29-35. [CrossRef]

77. Johannes, A.; Matter, A.; Schulin, R.; Weisskopf, P.; Baveye, P.C.; Boivin, P. Optimal organic carbon values for soil structure quality of arable soils. Does clay content matter? Geoderma 2017, 302, 14-21. [CrossRef]

78. Schäffer, B.; Schulin, R.; Boivin, P. Changes in shrinkage of restored soil caused by compaction beneath heavy agricultural machinery. Eur. J. Soil Sci. 2008, 59, 771-783. [CrossRef]

79. Imaz, M.J.; Virto, I.; Bescansa, P.; Enrique, A.; Fernandez-Ugalde, O.; Karlen, D.L. Soil quality indicator response to tillage and residue management on semi-arid Mediterranean cropland. Soil Tillage Res. 2010, 107, 17-25. [CrossRef]

80. Fernández-Ugalde, O.; Virto, I.; Bescansa, P.; Imaz, M.J.; Enrique, A.; Karlen, D.L. No-tillage improvement of soil physical quality in calcareous, degradation-prone, semiarid soils. Soil Tillage Res. 2009, 106, 29-35. [CrossRef]

81. Powlson, D.S.; Bhogal, A.; Chambers, B.J.; Coleman, K.; Macdonald, A.J.; Goulding, K.W.T.; Whitmore, A.P. The potential to increase soil carbon stocks through reduced tillage or organic material additions in England and Wales: A case study. Agric. Ecosyst. Environ. 2012, 146, 23-33. [CrossRef]

82. Blanco-Canqui, H.; Ruis, S.J. No-tillage and soil physical environment. Geoderma 2018, 326, 164-200. [CrossRef]

83. Nunes, M.R.; Karlen, D.L.; Moorman, T.B. Tillage intensity effects on soil structure indicators-A US meta-analysis. Sustainability 2020, 12, 2071. [CrossRef]

84. Virto, I.; Imaz, M.J.; Enrique, A.; Hoogmoed, W.; Bescansa, P. Burning crop residues under no-till in semi-arid land, Northern Spain-Effects on soil organic matter, aggregation, and earthworm populations. Aust. J. Soil Res. 2007, 45, 414-421. [CrossRef]

85. González-Sánchez, E.J.; Ordóñez-Fernández, R.; Carbonell-Bojollo, R.; Veroz-González, O.; Gil-Ribes, J.A. Meta-analysis on atmospheric carbon capture in Spain through the use of conservation agriculture. Soil Tillage Res. 2012, 122, 52-60. [CrossRef]

86. Mary, B.; Clivot, H.; Blaszczyk, N.; Labreuche, J.; Ferchaud, F.; Joint, B.; De Liège, U.; De Lille, U.; De Picardie, U.; Verne, J. Soil carbon storage and mineralization rates are affected by carbon inputs rather than physical disturbance: Evidence from a 47-year tillage experiment. Agric. Ecosyst. Environ. 2020, 299, 106972. [CrossRef]

87. Powlson, D.S.; Stirling, C.M.; Jat, M.L.; Gerard, B.G.; Palm, C.A.; Sanchez, P.A.; Cassman, K.G. Limited potential of no-till agriculture for climate change mitigation. Nat. Clim. Chang. 2014, 4, 678-683. [CrossRef]

88. Gómez, J.A.; Llewellyn, C.; Basch, G.; Sutton, P.B.; Dyson, J.S.; Jones, C.A. The effects of cover crops and conventional tillage on soil and runoff loss in vineyards and olive groves in several Mediterranean countries. Soil Use Manag. 2011, $27,502-514$. [CrossRef]

89. Priori, S.; Pellegrini, S.; Vignozzi, N.; Costantini, E.A.C. Soil Physical-Hydrological Degradation in the Root-Zone of Tree Crops: Problems and Solutions. Agronomy 2020, 11, 68. [CrossRef]

90. Schmidt, E.S.; Villamil, M.B.; Amiotti, N.M. Soil quality under conservation practices on farm operations of the southern semiarid pampas region of Argentina. Soil Tillage Res. 2018, 176, 85-94. [CrossRef]

91. Anderson, S.H.; Gantzer, C.J.; Brown, J.R. Soil physical properties after 100 years of continuous cultivation. J. Soil Water Conserv. 1990, 45, 117-121. 
92. Bottinelli, N.; Menasseri-Aubry, S.; Cluzeau, D.; Hallaire, V. Response of soil structure and hydraulic conductivity to reduced tillage and animal manure in a temperate loamy soil. Soil Use Manag. 2013, 29, 401-409. [CrossRef]

93. Byrnes, R.C.; Eastburn, D.J.; Tate, K.W.; Roche, L.M. A Global Meta-Analysis of Grazing Impacts on Soil Health Indicators. J. Environ. Qual. 2018, 47, 758-765. [CrossRef] [PubMed]

94. Evans, C.R.W.; Krzic, M.; Broersma, K.; Thompson, D.J. Long-term grazing effects on grassland soil properties in southern British Columbia. Can. J. Soil Sci. 2012, 92, 685-693. [CrossRef]

95. Lal, R. Soil organic matter and water retention. Agron. J. 2020, 112, 3265-3277. [CrossRef]

96. Minasny, B.; McBratney, A.B. Limited effect of organic matter on soil available water capacity. Eur. J. Soil Sci. 2018, 69, 39-47. [CrossRef]

97. Wall, A.; Heiskanen, J. Water-retention characteristics and related physical properties of soil on afforested agricultural land in Finland. For. Ecol. Manag. 2003, 186, 21-32. [CrossRef]

98. Yost, J.L.; Hartemink, A.E. Effects of carbon on moisture storage in soils of the Wisconsin Central Sands, USA. Eur. J. Soil Sci. 2019, 70, 565-577. [CrossRef]

99. Li, L.; Huang, G.; Zhang, R.; Bill, B.; Guangdi, L.; Kwong, Y.C. Benefits of Conservation Agriculture on Soil and Water Conservation and Its Progress in China. Agric. Sci. China 2011, 10, 850-859. [CrossRef]

100. Ali, A.B.; Elshaikh, N.A.; Hong, L.; Adam, A.B.; Haofang, Y. Conservation tillage as an approach to enhance crops water use efficiency. Acta Agric. Scand. Sect. B Soil Plant Sci. 2017, 67, 252-262. [CrossRef]

101. Fonteyne, S.; Gamiño, M.M.; Tejeda, A.S.; Verhulst, N. Conservation Agriculture Improves Long-term Yield and Soil Quality in Irrigated Maize-oats Rotation. Agronomy 2019, 9, 845. [CrossRef]

102. Virto, I.; Imaz, M.J.; Fernandez-Ugalde, O.; Urrutia, I.; Enrique, A.; Bescansa, P. Soil quality evaluation following the implementation of permanent cover crops in semi-arid vineyards. Organic matter, physical and biological soil properties. Span. J. Agric. Res. 2012, 10, 1121-1132. [CrossRef]

103. Indoria, A.K.; Srinivasa Rao, C.; Sharma, K.L.; Sammi Reddy, K. Conservation agriculture-A panacea to improve soil physical health. Curr. Sci. 2017, 112, 52-61. [CrossRef]

104. Mtyobile, M.; Muzangwa, L.; Mnkeni, P.N.S. Tillage and crop rotation effects on soil carbon and selected soil physical properties in a Haplic Cambisol in Eastern Cape, South Africa. Soil Water Res. 2020, 15, 47-54. [CrossRef]

105. Hao, Y.; He, Z. Effects of grazing patterns on grassland biomass and soil environments in China: A meta-analysis. PLoS ONE 2019, 14, 1-15. [CrossRef] [PubMed]

106. Milchunas, D.; Lauenroth, W. Quantitative effects of grazing on vegetation and soils over a global range of environments: Ecological Archives M063-001. Ecol. Monogr. 1993, 63, 327-366. [CrossRef]

107. Pulido, M.; Schnabel, S.; Lavado Contador, J.F.; Lozano-Parra, J.; González, F. The Impact of Heavy Grazing on Soil Quality and Pasture Production in Rangelands of SW Spain. Land Degrad. Dev. 2018, 29, 219-230. [CrossRef]

108. Dong, W.; Yu, L.; Gao-Lin, W.; Lu-Ming, D.; Zheng, Y.; Hong-Min, H. Effect of rest-grazing management on soil water and carbon storage in an arid grassland (China). J. Hydrol. 2015, 527, 754-760. [CrossRef]

109. Mcsherry, M.E.; Ritchie, M.E. Effects of grazing on grassland soil carbon: A global review. Glob. Chang. Biol. 2013, 19, 1347-1357. [CrossRef]

110. Chan, K.Y.; Heenan, O.P. The influence of crop rotation on soil structure and soil physical properties under conventional tillage. Soil Tillage Res. 1996, 37, 113-125. [CrossRef]

111. Trost, B.; Prochnow, A.; Drastig, K.; Meyer-Aurich, A.; Ellmer, F.; Baumecker, M. Irrigation, soil organic carbon and N2O emissions. A review. Agron. Sustain. Dev. 2013, 33, 733-749. [CrossRef]

112. Pittelkow, C.M.; Liang, X.; Linquist, B.A.; Jan van Groenigen, K.; Lee, J.; Lundy, M.E.; van Gestel, N.; Six, J.; Venterea, R.T.; van Kessel, C. Productivity limits and potentials of the principles of conservation agriculture. Nature 2014, 517. [CrossRef] [PubMed]

113. European Commission. The European Green Deal. In Summary for Policymakers; Cambridge University Press: Cambridge, UK, 2019; Volume 53, p. 24. [CrossRef] 